\title{
Questionnaire Investigation on the Needs at Fuji City and its Sensibility Analysis Utilizing Bayesian Network
}

\author{
Tsuyoshi Aburai ${ }^{1}$, Akane Okubo $^{2}$, Daisuke Suzuki ${ }^{3} \&$ Kazuhiro Takeyasu ${ }^{4}$ \\ ${ }^{1}$ Tokushima University, Japan \\ ${ }^{2}$ NIHON University Junior College, Japan \\ ${ }^{3}$ Fujisan Area Management Company, Japan \\ ${ }^{4}$ College of Business Administration, Tokoha University, Japan \\ Correspondence: Tsuyoshi Aburai, Tokushima University, Japan.
}

Received: December 18, 2017

Accepted: January 11,2018

Online Published: January 18, 2018

doi:10.5539/ibr.v11n2p125

URL: https://doi.org/10.5539/ibr.v11n2p125

\begin{abstract}
Shopping streets at local city in Japan became old and are generally declining. In this paper, we handle the area rebirth and/or regional revitalization of shopping street. We focus on Fuji city in Japan. Four big festivals are held at Fuji city. Many people visit these festivals including residents in that area. Therefore a questionnaire investigation to the residents and visitors is conducted during these periods in order to clarify residents and visitors needs for the shopping street, and utilize them to the plan building of the area rebirth and/or regional revitalization of shopping street. These are analyzed by using Bayesian Network. Sensitivity analysis is also conducted. As there are so many items, we focus on "The image of the surrounding area at this shopping street" and pick up former half and make sensitivity analysis in this paper. The analysis utilizing Bayesian Network enabled us to visualize the causal relationship among items. Furthermore, sensitivity analysis brought us estimating and predicting the prospective visitors. These are utilized for constructing a much more effective and useful plan building. We have obtained fruitful results. To confirm the findings by utilizing the new consecutive visiting records would be the future works to be investigated.
\end{abstract}

Keywords: Fuji City, area rebirth, regional vitalization, festival, Bayesian network

\section{Introduction}

Shopping streets at local city in Japan are generally declining. It is because most of them were built in the so-called "High Growth Period (1954-1973)". Therefore they became old and area rebirth and/or regional revitalization are required everywhere.

There are many papers published concerning area rebirth or regional revitalization. Inoue (2017) has pointed out the importance of tourism promotion. Ingu et al. (2017) developed the project of shutter art to Wakkanai Chuo shopping street in Hokkaido, Japan. Ohkubo (2017) has made a questionnaire research at Jigenji shopping street in Kagoshima Prefecture, Japan and analyzed the current condition and future issues. For about tourism, many papers are presented from many aspects as follows.

Yoshida et al. designed and conducted a visitor survey on the spot, which used a questionnaire to investigate the activities of visitors to the Ueno district in Taito ward, Tokyo. Doi et al. analyzed the image of the Izu Peninsula as a tourist destination in their 2003 study "Questionnaire Survey on the Izu Peninsula." Kano conducted tourist behavior studies in Atami city in 2008, 2009, 2014 and in other years. Aburai et.al (2013a, 2013b, 2013c, 2014d) have made the bayesian network analysis on SNS.

In this paper, we handle the area rebirth and/or regional revitalization of shopping street. We focus on Fuji city in Japan. Fuji city is located in Shizuoka Prefecture. Mt. Fuji is very famous all around the world and we can see its beautiful scenery from Fuji city, which is at the foot of Mt. Fuji. There are two big shopping street in Fuji city. One is Yoshiwara shopping street and another one is Fuji shopping street. They became old and building area rebirth and regional revitalization plan have started. Following investigation was conducted by the joint research group (Fuji Chamber of Commerce \& Industry, Fujisan Area Management Company, Katsuyama Maruyama Architects, Kougakuin University and Tokoha University). The main project activities are as follows. 
A. Investigation on the assets which are not in active use

B. Questionnaire Investigation to Entrepreneur

C. Questionnaire Investigation to the residents and visitors

After that, area rebirth and regional revitalization plan were built.

In this paper, we handle above stated C.

Four big festivals are held at Fuji city. Two big festivals are held at Yoshiwara district(Yoshiwara shopping street) and two big festivals at Fuji district(Fuji shopping street).

At Yoshiwara district, Yoshiwara Gion Festival is carried out during June and Yoshiwara Shukuba (post-town) Festival is held during October. On the other hand, Kinoene Summer Festival is conducted during August and Kinoene Autumn Festival is performed during October at Fuji district. Many people visit these festivals including residents in that area.

Therefore questionnaire investigation of $\mathrm{C}$ is conducted during these periods.

Finally, we have obtained 982 sheets (Yoshiwara district: 448, Fuji district: 534).

Basic statistical analysis and Bayesian Network analysis are executed based on that.

In this paper, a questionnaire investigation is executed in order to clarify residents and visitors' needs for the shopping street, and utilize them to the plan building of the area rebirth and/or regional revitalization of shopping street. These are analyzed by using Bayesian Network. Sensitivity analysis is also conducted. As there are so many items, we focus on "The image of the surrounding area at this shopping street" and pick up former half and make sensitivity analysis in this paper. By that model, the causal relationship is sequentially chained by the characteristics of visitors, the purpose of visiting and the image of the surrounding area at this shopping street. The analysis utilizing Bayesian Network enabled us to visualize the causal relationship among items. Furthermore, sensitivity analysis brought us estimating and predicting the prospective visitors.

Some interesting and instructive results are obtained.

The rest of the paper is organized as follows. Outline of questionnaire investigation is stated in section 2. In section 3, Bayesian Network analysis is executed which is followed by the sensitivity analysis in section 4 . Remarks is stated in section 5 .

\section{Outline and the Basic Statistical Results of the Questionnaire Research}

\subsection{Outline of the Questionnaire Research}

A questionnaire investigation to the residents and visitors is conducted during these periods in order to clarify residents and visitors' needs for the shopping street, and utilize them to the plan building of the area rebirth and/or regional revitalization of shopping street. The outline of questionnaire research is as follows. Questionnaire sheet is attached in Appendix 1.

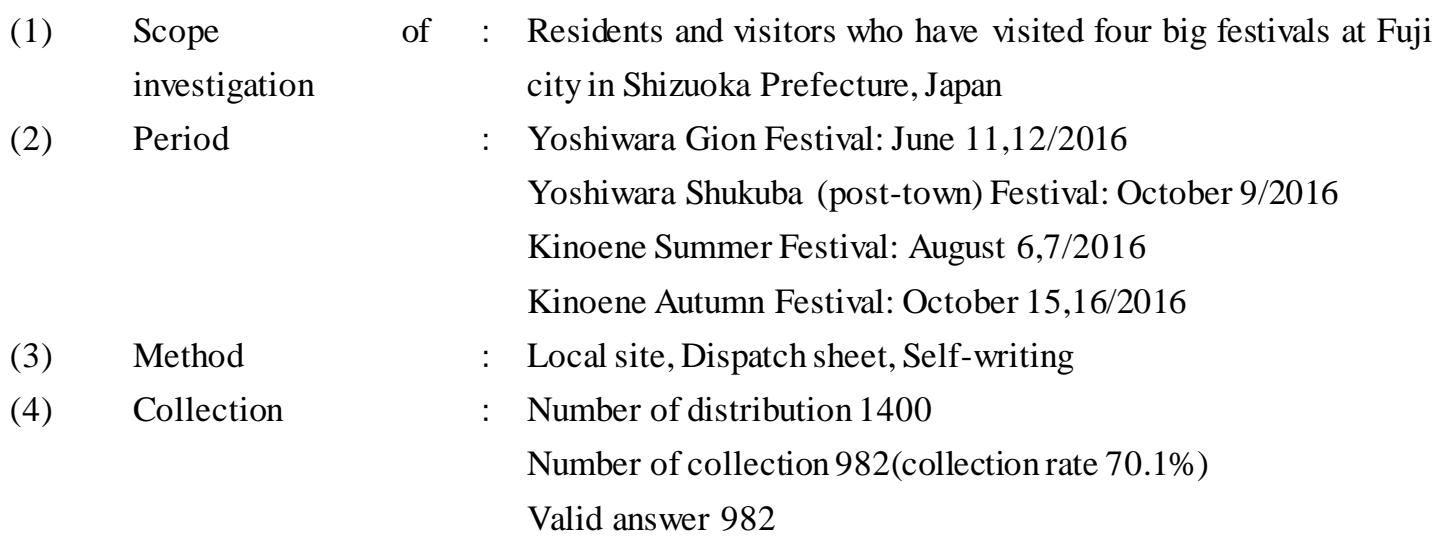

\subsection{Basic Statistical Results}

Now, we show the main summary results by single variable.

2.2.1 Characteristics of Answers

1) Sex (Q7)

Male $48.9 \%$, Female 51.1\% 
These are exhibited in Figure 1.

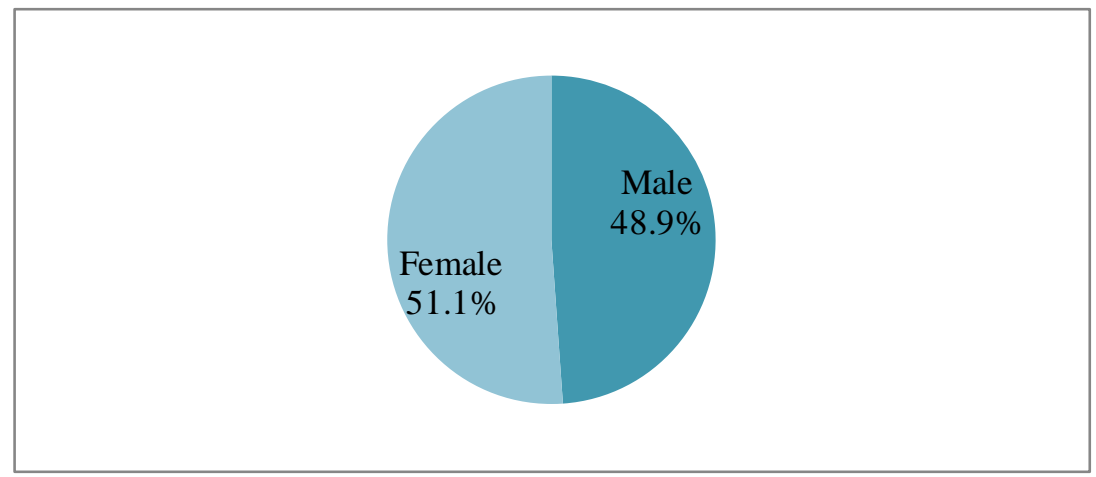

Figure 1. Sex (Q7)

2) Age (Q8)

$10^{\text {th }} 16.2 \%, 20^{\text {th }} 14.8 \%, 30^{\text {th }} 22.4 \%, 40^{\text {th }} 17.4 \%, 50^{\text {th }} 11.6 \%, 60^{\text {th }} 10.5 \%$, More than $707.1 \%$

These are exhibited in Figure 2.

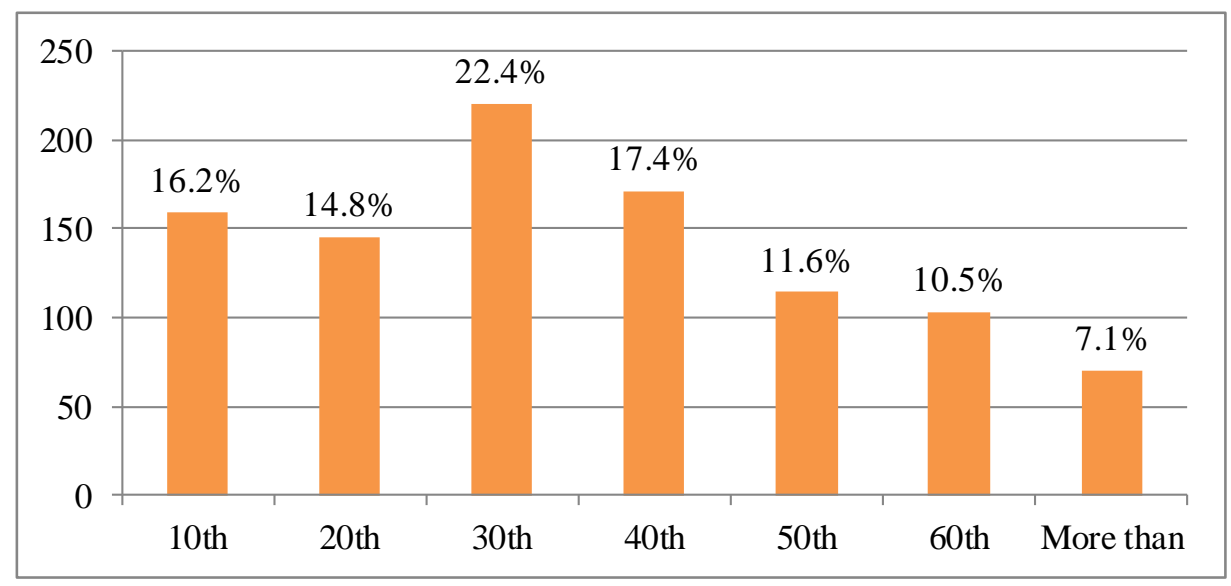

Figure 2. Age (Q8)

3) Residence (Q9)

a. Fuji city $56.4 \%$, b. Fujinomiya city $18.0 \%$, c. Numazu city $7.2 \%$, d. Mishima city $2.3 \%$, e. Shizuoka city $4.2 \%$, F. Else (in Shizuoka Prefecture) 5.1\%, g. Outside of Shizuoka Prefecture 6.9\%

These are exhibited in Figure 3.

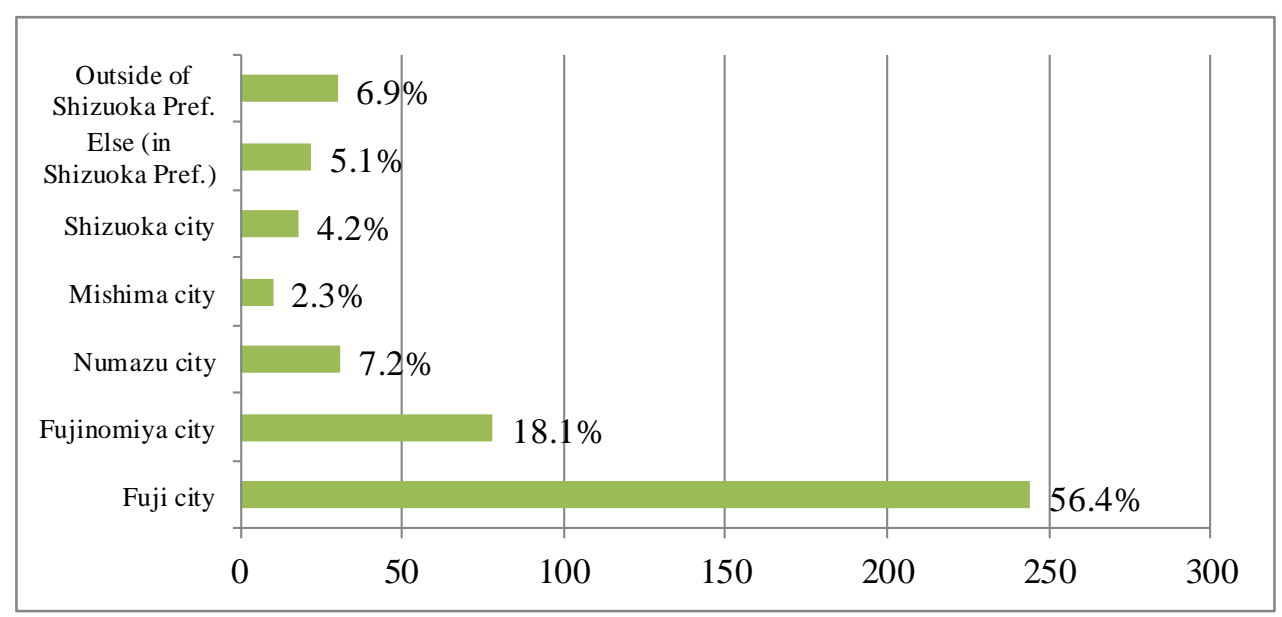

Figure 3. Residence (Q9) 
4) How often do you come to this shopping street? (Q1)

Everyday $17.4 \%$, More than 1 time a week $16.5 \%$, More than 1 time a month $25.8 \%$,

More than 1 time a year $31.6 \%$, First time $4 \%$, Not filled in $4.8 \%$

These are exhibited in Figure 4.

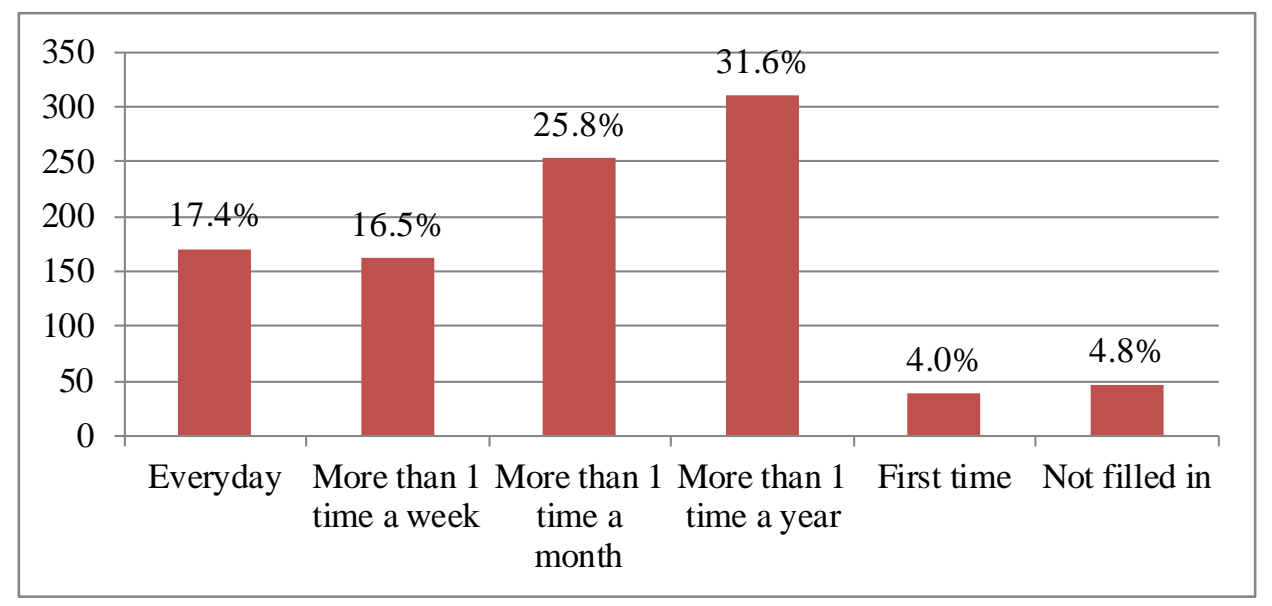

Figure 4. How often do you come to this shopping street? (Q1)

5) What is the purpose of visiting here? (Q2)

Shopping $18.8 \%$, Eating and drinking $13.4 \%$, Business 7.4\%, Celebration, event 40.2\%,

Leisure, amusement $4.0 \%$, miscellaneous $16.1 \%$

These are exhibited in Figure 5.

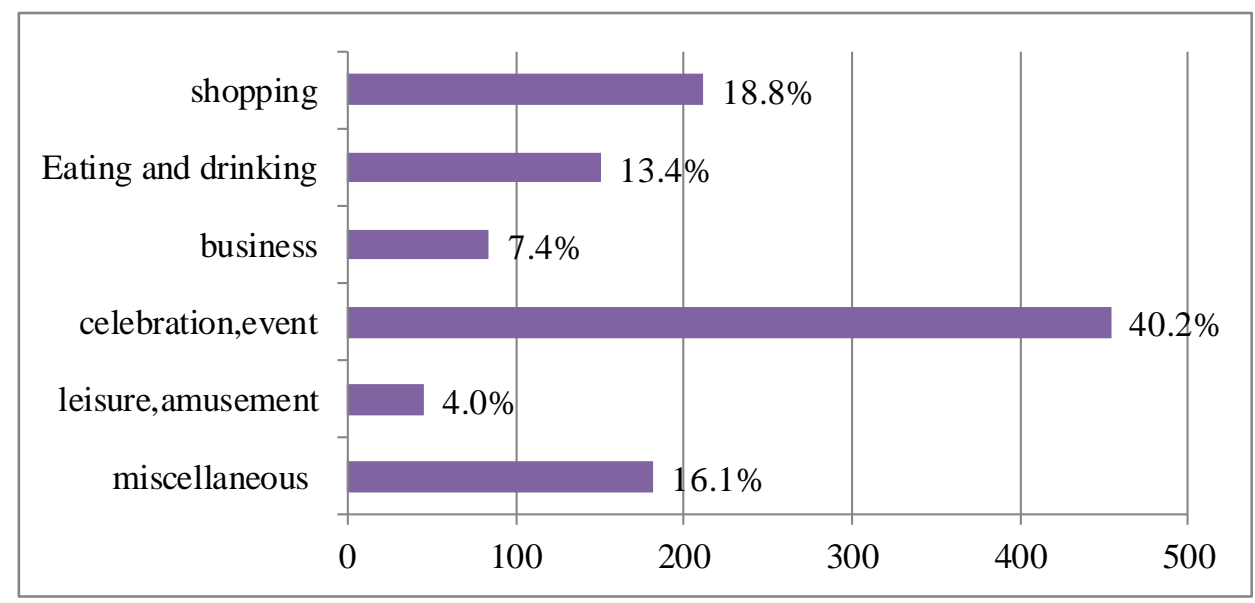

Figure 5. What is the purpose of visiting here? (Q2)

6) How do you feel about the image of the surrounding area at this shopping street? (Q3)

These are exhibited in Figure 6. 


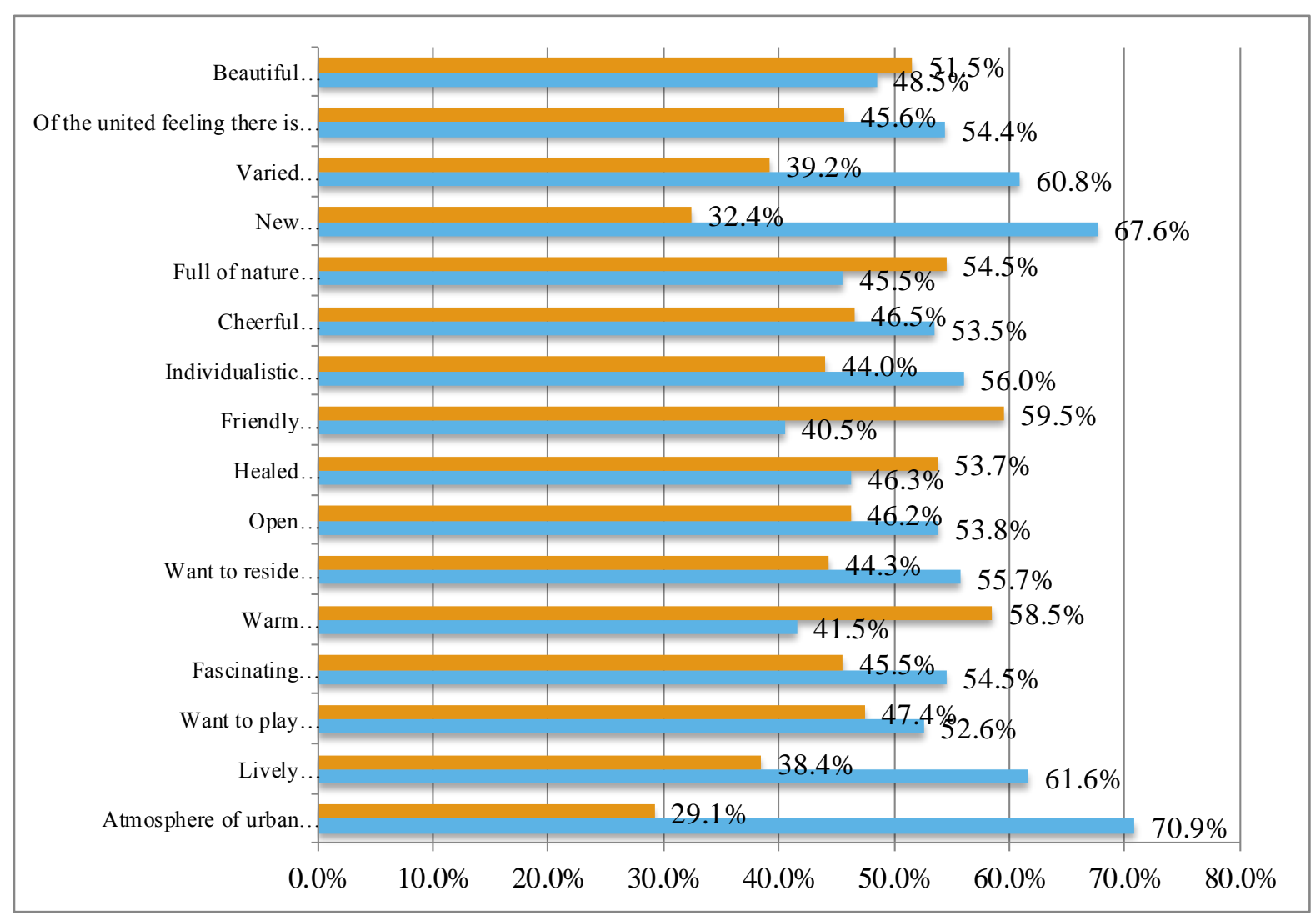

Figure 6. How do you feel about the image of the surrounding area at this shopping street? (Q3)

7) There are many old building at the age of nearly 50 years. Do you think we can still use them? (Q4)

Can use it $44.1 \%$, Cannot use it $31.4 \%$, Have no idea $24.5 \%$

These are exhibited in Figure 7.

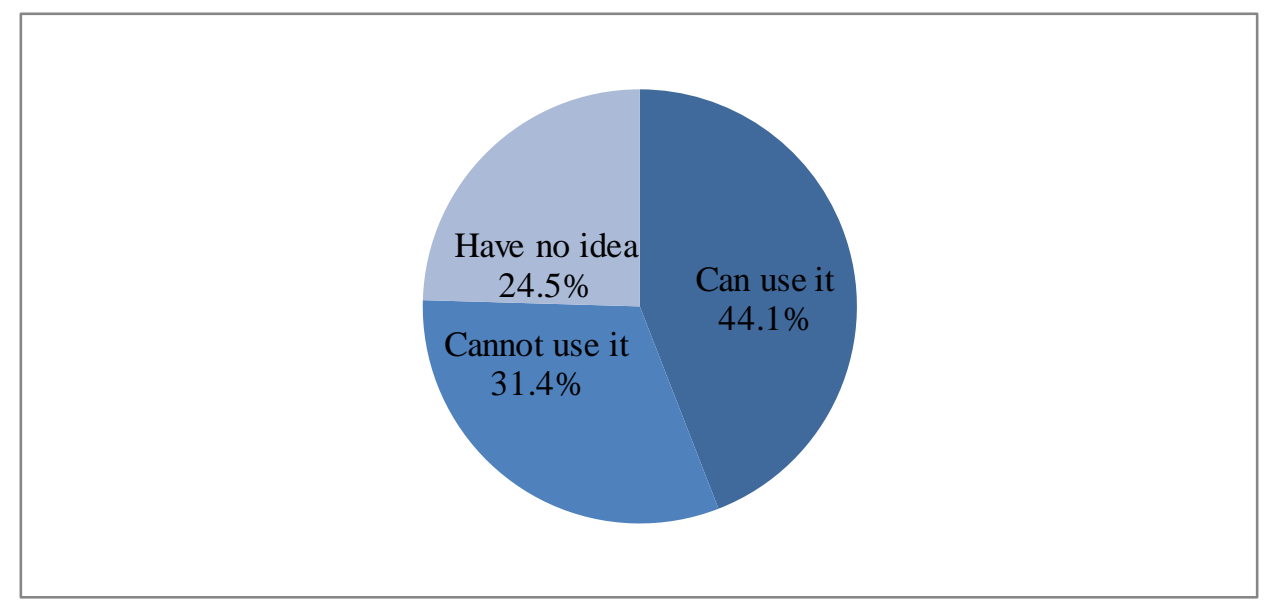

Figure 7. There are many old building at the age of nearly 50 years. Do you think we can still use them?(Q4)

\section{Bayesian Network Anal ysis}

In constructing Bayesian Network, it is required to check the causal relationship among groups of items.

Based on this, a model is built as is shown in Figure 8. 


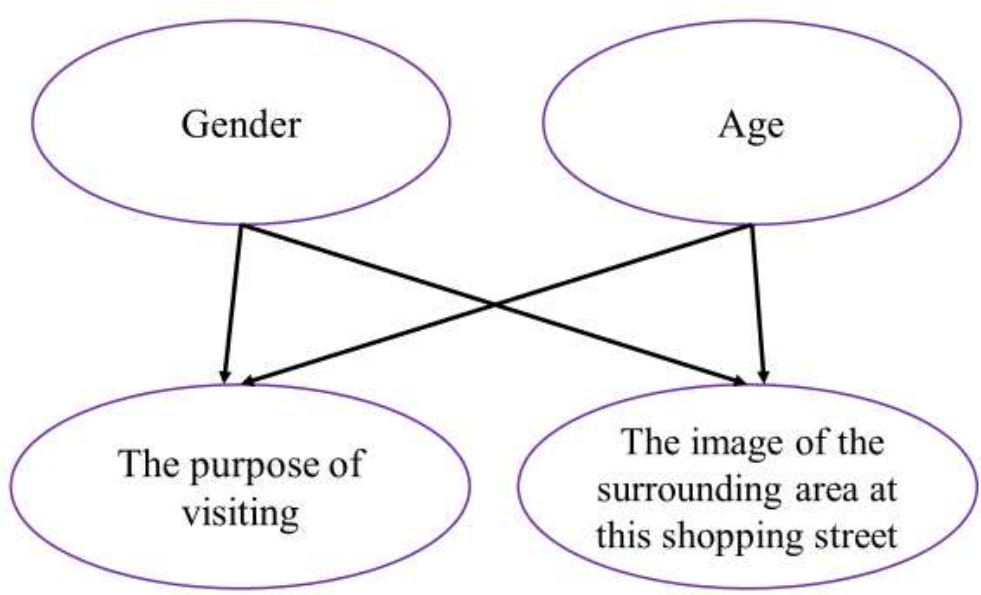

Figure 8. A Built Model

We used BAYONET software (http://www.msi.co.jp/BAYONET/). When plural nodes exist in the same group, it occurs that causal relationship is hard to set a priori. In that case, BAYONET system set the sequence automatically utilizing AIC standard. Node and parameter of Figure 8 are exhibited in Table 1.

Table 1. Node and Parameter

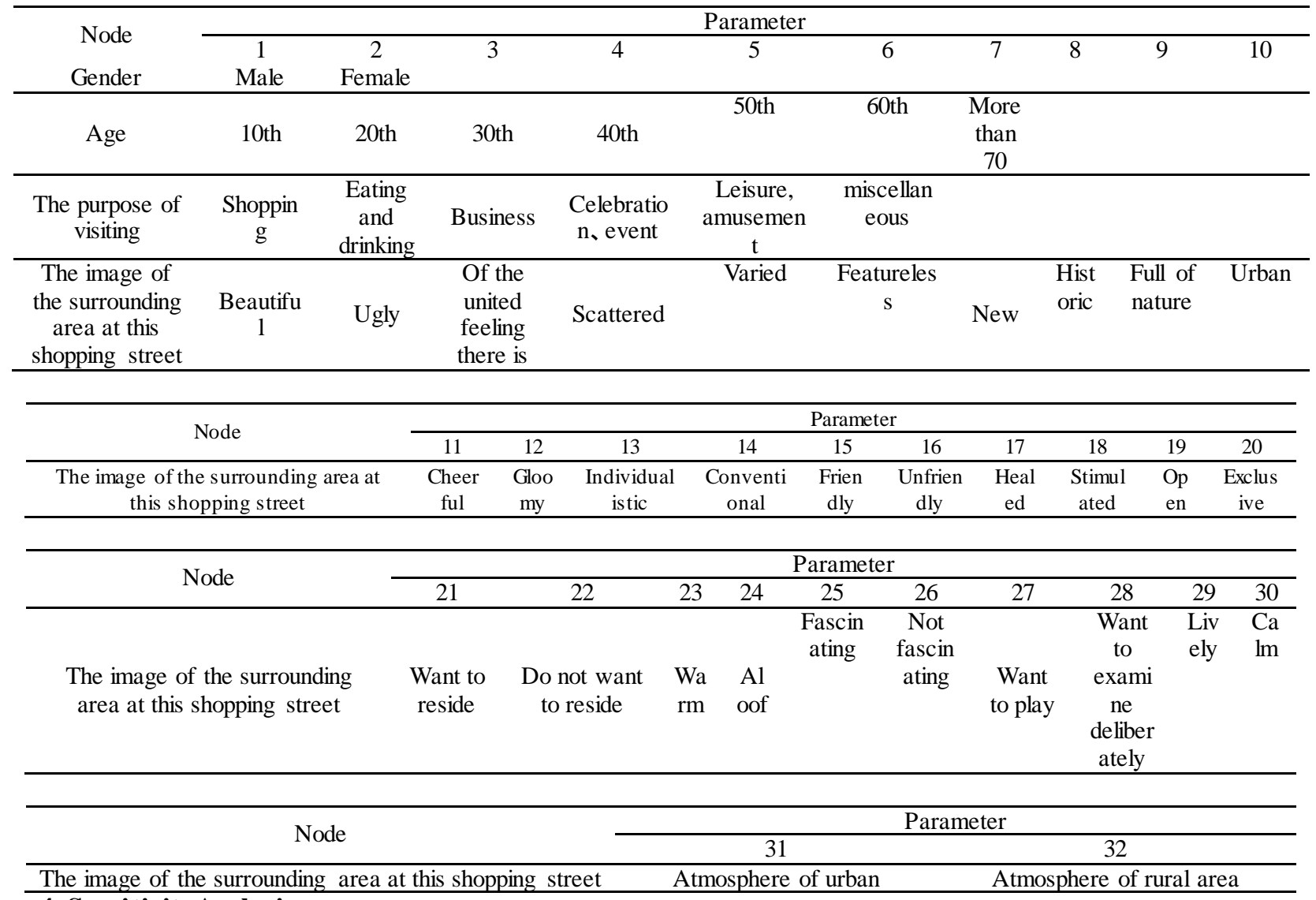

\section{Sensitivity Analysis}

Now, posterior probability is calculated by setting evidence as, for example, 1.0. Comparing Prior probability and Posterior probability, we can seek the change and confirm the preference or image of the surrounding area at this shopping street. We set evidence to all parameters. Therefore the analysis volume becomes too large. In this paper, we focus on "The image of the surrounding area at this shopping street" and pick up former half and make sensitivity analysis. We prepare another paper for the rest of them.

As stated above, we set evidence for each parameter, and the calculated posterior probability is exhibited in Appendix 2. The value of "Posterior probability - Prior probability" (we call this "Difference of probability" 
hereafter) is exhibited in Appendix 3. The sensitivity analysis is executed by mainly using this table.

Here, we classify each item by the strength of the difference of probability.

- Strong $(++,--)$ : Select major parameter of which absolute value of difference of probability is more than 0.05

- Medium (+,-): Select major parameter of which absolute value of difference of probability is more than 0.01

- Weak: Else

In selecting items, negative value does not necessarily have distinct meaning, therefore we mainly pick up positive value in the case meaning is not clear.

Now we examine each for Strong and Medium case.

\subsection{Sensitively Analysis for "The Image Of the Surrounding Area at this Shopping Street"}

1) Setting evidence to "Beautiful"

After setting evidence to "Beautiful", the result is exhibited in Table 2.

Table 2. Setting evidence to "Beautiful" case

\begin{tabular}{lc}
\hline Eating and drinking & - \\
Scattered & + \\
Fascinating & + \\
Want to play & + \\
Lively & - \\
Male & + \\
Female & ++ \\
Age: 10th & ++ \\
Age: 20th & + \\
Age: 30th & -- \\
Age: 40th & -- \\
Age: 50th & -- \\
Age: 60th & + \\
Age: More than 70 & +
\end{tabular}

We can observe that "Those who have an image of the surrounding area at this shopping street as "Beautiful" had come under the image of the surrounding area at this shopping street as "Fascinating", "Want to play" or "Lively" of an age of " $10^{\text {th }}$, ," $20^{\text {th }}$, " 30 th" or "More than 70 " in which the gender is "Female". (Strong part is indicated by bold font.)

2) Setting evidence to "Ugly"

After setting evidence to "Ugly", the result is exhibited in Table 3.

Table 3. Setting evidence to "Ugly" case

\begin{tabular}{lc}
\hline Want to play & - \\
Age: 10th & - \\
Age: 20 th & - \\
Age: 30th & + \\
Age: 40th & ++ \\
Age: 50th & + \\
Age: More than 70 & + \\
\hline
\end{tabular}

We can observe that "Those who have an image of the surrounding area at this shopping street as "Ugly" had come by an age of "40th ", "50th" or "More than 70".

3) Setting evidence to "Of the united feeling there is"

After setting evidence to "Of the united feeling there is", the result is exhibited in Table 4. 
Table 4. Setting evidence to "Of the united feeling there is" case

\begin{tabular}{|c|c|}
\hline Eating and drinking & - \\
\hline Cheerful & + \\
\hline Individua listic & + \\
\hline Friendly & + \\
\hline Unfriendly & - \\
\hline Healed & + \\
\hline Stimulated & - \\
\hline Open & + \\
\hline Fascinating & + \\
\hline Want to play & + \\
\hline Lively & + \\
\hline Atmosphere of urban & + \\
\hline Age: 10th & ++ \\
\hline Age: 20 th & + \\
\hline Age: 30 th & -- \\
\hline Age: 40th & + \\
\hline Age: 50th & -- \\
\hline Age: 60 th & -- \\
\hline Age: More than 70 & -- \\
\hline
\end{tabular}

We can observe that "Those who have an image of the surrounding area at this shopping street as "Of the united feeling there is" had come under the image of the surrounding area at this shopping street as "Cheerful", "Individualistic", "Friendly", "Healed", "Open", "Fascinating", "Want to play", "Lively" or "Atmosphere of urban" of an age of "10th","20th" or "40th".

4) Setting evidence to "Scattered"

After setting evidence to "Scattered", the result is exhibited in Table 5.

Table 5. Setting evidence to "Scattered" case

\begin{tabular}{|c|c|}
\hline Shopping & + \\
\hline Eating and drinking & + \\
\hline Varied & - \\
\hline Cheerful & - \\
\hline Individua listic & - \\
\hline Friendly & - \\
\hline Unfriendly & + \\
\hline Healed & - \\
\hline Stimulated & + \\
\hline Open & - \\
\hline Aloof & + \\
\hline Fascinating & - \\
\hline Want to play & - \\
\hline Lively & - \\
\hline Atmosphere of urban & - \\
\hline Age: 10th & -- \\
\hline Age: 20th & -- \\
\hline Age: 30 th & - \\
\hline Age: 40th & ++ \\
\hline Age: 50 th & ++ \\
\hline Age: 60 th & ++ \\
\hline Age: More than 70 & ++ \\
\hline \multirow{2}{*}{\multicolumn{2}{|c|}{$\begin{array}{l}\text { bserve that "Those wh } \\
\text { e with the purpose of } \\
\text { ng area at this shoppin } \\
\text { "More than } 70 " \text {. } \\
\text { evidence to "Varied" }\end{array}$}} \\
\hline & \\
\hline \multicolumn{2}{|c|}{ ing evidence to "Varied", the result is exhibited in Table 6.} \\
\hline \multicolumn{2}{|c|}{ Setting evidence to "Varied" case } \\
\hline Age: 10th & ++ \\
\hline Age: 20th & + \\
\hline Age: 40th & -- \\
\hline Age: 50 th & + \\
\hline Age: 60 th & -- \\
\hline Age: More than 70 & + \\
\hline
\end{tabular}


We can observe that "Those who have an image of the surrounding area at this shopping street as "Varied" had come by an age of "10th","20th", "50th" or "More than 70".

6) Setting Evidence to "Featureless"

After setting evidence to "Featureless", the result is exhibited in Table 7.

Table 7. Setting evidence to "Featureless" case

\begin{tabular}{lc}
\hline Individualistic & - \\
Fascinating & - \\
Want to play & - \\
Lively & -- \\
Age: 10th & -- \\
Age: 20th & + \\
Age: 30th & + \\
Age: 40th & -- \\
Age: 50th & ++ \\
Age: 60th & ++ \\
Age: More than 70 & + \\
\hline
\end{tabular}

We can observe that "Those who have an image of the surrounding area at this shopping street as "Featureless" had come by an age of "30th","40th", "60th" or "More than 70".

7) Setting Evidence to "New"

After setting evidence to "New", the result is exhibited in Table 8 .

Table 8. Setting evidence to "New" case

\begin{tabular}{lc}
\hline Male & - \\
Female & + \\
Age: 10th & - \\
Age: 20 th & + \\
Age: 30th & - \\
Age: 60th & + \\
\hline
\end{tabular}

We can observe that "Those who have an image of the surrounding area at this shopping street as "New" had come by an age of "20th" or "60th" in which the gender is "Female".

8) Setting evidence to "Historic"

After setting evidence to "Historic", the result is exhibited in Table 9.

Table 9. Setting evidence to "Historic" case

\begin{tabular}{lc}
\hline Age: 20th & - \\
Age: 30th & + \\
Age: 50th & -- \\
Age: More than 70 & + \\
\hline
\end{tabular}

We can observe that "Those who have an image of the surrounding area at this shopping street as "Historic" had come by an age of "30th" or "More than 70".

9) Setting evidence to "Full of nature"

After setting evidence to "Full of nature", the result is exhibited in Table 10.

Table 10. Setting evidence to "Full of nature" case

\begin{tabular}{lc}
\hline Eating and drinking & - \\
Fascinating & - \\
Male & + \\
Female & ++ \\
Age: 10th & + \\
Age: 20th & -- \\
Age: 40th & - \\
Age: 50th & - \\
Age: 60th & ++ \\
Age: More than 70 & + \\
\hline
\end{tabular}

We can observe that "Those who have an image of the surrounding area at this shopping street as "Full of nature" had come under the image of the surrounding area at this shopping street as "Fascinating" of an age of "10th","20th" or "More than 70" in which the gender is "Female". 


\section{0) Setting evidence to "Urban"}

After setting evidence to "Urban", the result is exhibited in Table 11.

Table 11. Setting evidence to "Urban" case

\begin{tabular}{lc}
\hline Age: 10th & + \\
Age: 20th & - \\
Age: 30th & - \\
Age: 40th & - \\
Age: 60th & + \\
Age: More than 70 & + \\
\hline
\end{tabular}

We can observe that "Those who have an image of the surrounding area at this shopping street as "Urban" had come by an age of "10th","60th", or "More than 70".

11) Setting evidence to "Cheerful"

After setting evidence to "Cheerful", the result is exhibited in Table 12.

Table 12. Setting evidence to "Cheerful" case

\begin{tabular}{lc}
\hline Eating and drinking & - \\
Of the united feeling there is & + \\
Scattered & + \\
Individualistic & + \\
Friendly & - \\
Unfriendly & + \\
Healed & - \\
Stimulated & + \\
Open & + \\
Fascinating & + \\
Want to play & + \\
Lively & + \\
Atmosphere of urban & + \\
Age: 10th & + \\
Age: 20th & - \\
Age: 30th & - \\
Age: 40th & - \\
Age: 50th & - \\
Age: 60th & - \\
Age: More than 70 & - \\
\hline
\end{tabular}

We can observe that "Those who have an image of the surrounding area at this shopping street as "Cheerful" had come under the image of the surrounding area at this shopping street as "Of the united feeling there is", "Individualistic", "Healed", "Open", "Fascinating", "Want to play", "Lively" or "Atmosphere of urban" of an age of "10th" or" 20 th".

12) Setting evidence to "Gloomy"

After setting evidence to "Gloomy", the result is exhibited in Table 13.

Table 13. Setting evidence to "Gloomy" case

\begin{tabular}{lc}
\hline Eating and drinking & + \\
Of the united feeling there is & + \\
Scattered & - \\
Individualistic & + \\
Unfriendly & - \\
Healed & - \\
Stimulated & - \\
Fascinating & - \\
Want to play & + \\
Lively & - \\
Male & - \\
Female & + \\
Age: 10th & + \\
Age: 50th & + \\
Age: 60th & + \\
Age: More than 70 & + \\
\hline
\end{tabular}

We can observe that "Those who have an image of the surrounding area at this shopping street as "Gloomy" had come with the purpose of visiting for "Eating and drinking" under the image of the surrounding area at this 
shopping street as "Scattered", "Unfriendly" or "Stimulated" of an age of "50th", "60th" or "More than 70" in which the gender is "Male".

13) Setting evidence to "Individualistic"

After setting evidence to "Individualistic", the result is exhibited in Table 14.

Table 14. Setting evidence to "Individualistic" case

\begin{tabular}{lc}
\hline Eating and drinking & - \\
Of the united feeling there is & - \\
Scattered & + \\
Cheerful & + \\
Friendly & + \\
Unfriendly & + \\
Healed & + \\
Fascinating & + \\
Want to play & + \\
Lively & + \\
Atmosphere of urban & -- \\
Age: 10th & - \\
Age: 30th & -- \\
Age: 40th & -- \\
Age: 60th & \\
Age: More than 70 &
\end{tabular}

We can observe that "Those who have an image of the surrounding area at this shopping street as "Individualistic" had come under the image of the surrounding area at this shopping street as "Of the united feeling there is", "Cheerful", "Friendly", "Healed", "Fascinating", "Want to play", "Lively" or "Atmosphere of urban" of an age of "10th".

14) Setting evidence to "Conventional"

After setting evidence to "Conventional", the result is exhibited in Table 15.

Table 15. Setting evidence to "Conventional" case

\begin{tabular}{lc}
\hline Eating and drinking & + \\
Of the united feeling there is & - \\
Cheerful & - \\
Friendly & + \\
Unfriendly & - \\
Fascinating & - \\
Want to play & - \\
Lively & - \\
Atmosphere of urban & + \\
Age: 10th & + \\
Age: 20th & + \\
Age: 30th & + \\
Age: 50th & + \\
Age: 60th & + \\
Age: More than 70 & + \\
\hline
\end{tabular}

We can observe that "Those who have an image of the surrounding area at this shopping street as "Conventional" had come with the purpose of visiting for "Eating and drinking" under the image of the surrounding area at this shopping street as "Unfriendly" of an age of "20th","30th", "50th", "60th" or "More than 70".

15) Setting evidence to "Friendly"

After setting evidence to "Friendly", the result is exhibited in Table 16. 
Table 16. Setting evidence to "Friendly" case

\begin{tabular}{lc}
\hline Shopping & - \\
Eating and drinking & - \\
Celebration、 event & + \\
Beautiful & + \\
Of the united feeling there is & - \\
Scattered & + \\
Varied & + \\
New & - \\
Cheerful & + \\
Gloomy & - \\
Individualistic & + \\
Conventional & - \\
Healed & + \\
Stimulated & - \\
Open & - \\
Exclusive & + \\
Aloof & - \\
Fascinating & + \\
Not Fascinating & + \\
Want to play & + \\
Lively & + \\
Atmosphere of urban & + \\
Age: 10th & Age: 20th \\
Age: 40th & - \\
Age: 50th & - \\
Age: 60th & - \\
Age: More than 70 & -- \\
\hline
\end{tabular}

We can observe that "Those who have an image of the surrounding area at this shopping street as "Friendly" had come under the image of the surrounding area at this shopping street as "Beautiful", "Of the united feeling there is", "Varied", "Cheerful", "Individualistic", "Healed", "Open", "Fascinating", "Want to play", "Lively" or "Atmosphere of urban" of an age of "10th".

16) Setting evidence to "Unfriendly"

After setting evidence to "Unfriendly", the result is exhibited in Table 17.

Table 17. Setting evidence to "Unfriendly" case

\begin{tabular}{lc}
\hline Individualistic & - \\
Want to play & - \\
Lively & -- \\
Age: 10th & + \\
Age: 20th & - \\
Age: 30th & - \\
Age: 40th & -- \\
Age: 50th & -- \\
Age: 60th & -- \\
Age: More than 70
\end{tabular}

We can observe that "Those who have an image of the surrounding area at this shopping street as "Unfriendly" had come by an age of "20th".

\section{Remarks}

The Results for Bayesian Network Analysis are as follows.

In the Bayesian Network Analysis, model was built under the examination of the causal relationship among items. Sensitively Analysis was conducted after that. The main result of sensitively analysis is as follows.

We can observe that "Those who have an image of the surrounding area at this shopping street as "Beautiful" had come under the image of the surrounding area at this shopping street as "Fascinating", "Want to play" or "Lively" of an age of "10th","20th", "30th" or "More than 70" in which the gender is "Female".

We can observe that "Those who have an image of the surrounding area at this shopping street as "Of the united feeling there is" had come under the image of the surrounding area at this shopping street as "Cheerful", "Individualistic", "Friendly", "Healed", "Open", "Fascinating", "Want to play", "Lively" or "Atmosphere of urban" of an age of "10th","20th " or "40th". 
We can observe that "Those who have an image of the surrounding area at this shopping street as "Scattered" had come with the purpose of visiting for "Shopping" or "Eating and drinking" under the image of the surrounding area at this shopping street as "Unfriendly", "Stimulated" or "Aloof" of an age of "40th","50th", "60th" or "More than 70".

We can observe that "Those who have an image of the surrounding area at this shopping street as "Cheerful" had come under the image of the surrounding area at this shopping street as "Of the united feeling there is", "Individualistic", "Healed", "Open", "Fascinating", "Want to play", "Lively" or "Atmosphere of urban" of an age of "10th" or" 20 th".

We can observe that "Those who have an image of the surrounding area at this shopping street as "Friendly" had come under the image of the surrounding area at this shopping street as "Beautiful", "Of the united feeling there is", "Varied", "Cheerful", "Individualistic", "Healed", "Open", "Fascinating", "Want to play", "Lively" or "Atmosphere of urban" of an age of "10th".

These results are very impressive to planners of tourism in Fuji city. These may be utilized to much more useful plan building for the activation of the related shopping street town.

\section{Conclusion}

Shopping streets at local city in Japan became old and are generally declining. In this paper, we handle the area rebirth and/or regional revitalization of shopping street. We focus on Fuji city in Japan. Four big festivals are held at Fuji city. Many people visit these festivals including residents in that area. Therefore a questionnaire investigation to the residents and visitors is conducted during these periods in order to clarify residents and visitors' needs for the shopping street, and utilize them to the plan building of the area rebirth and/or regional revitalization of shopping street. These are analyzed by using Bayesian Network. Sensitivity analysis is also conducted. As there are so many items, we focus on "The image of the surrounding area at this shopping street" and pick up former half and make sensitivity analysis in this paper. By that model, the causal relationship is sequentially chained by the characteristics of visitors, the purpose of visiting and the image of the surrounding area at this shopping street.

The Results for Bayesian Network Analysis are as follows.

In the Bayesian Network Analysis, model was built under the examination of the causal relationship among items. Sensitively Analysis was conducted after that. The main result of sensitively analysis is as follows.

We can observe that "Those who have an image of the surrounding area at this shopping street as "Of the united feeling there is" had come under the image of the surrounding area at this shopping street as "Cheerful", "Individualistic", "Friendly", "Healed", "Open", "Fascinating", "Want to play", "Lively" or "Atmosphere of urban" of an age of "10th","20th" or "40th".

We can observe that "Those who have an image of the surrounding area at this shopping street as "Cheerful" had come under the image of the surrounding area at this shopping street as "Of the united feeling there is", "Individualistic", "Healed", "Open", "Fascinating", "Want to play", "Lively" or "Atmosphere of urban" of an age of "10th" or"20th".

We can observe that "Those who have an image of the surrounding area at this shopping street as "Friendly" had come under the image of the surrounding area at this shopping street as "Beautiful", "Of the united feeling there is", "Varied", "Cheerful", "Individualistic", "Healed", "Open", "Fascinating", "Want to play", "Lively" or "Atmosphere of urban" of an age of "10th".

The analysis utilizing Bayesian Network enabled us to visualize the causal relationship among items. Furthermore, sensitivity analysis brought us estimating and predicting the prospective visitors. These are utilized for constructing a much more effective and useful plan building. There are few papers which applies Bayesian Network to the tourism theme. This may be the first trial and has significant meaning.

Although it has a limitation that it is restricted in the number of research, we could obtain the fruitful results. To confirm the findings by utilizing the new consecutive visiting records would be the future works to be investigated.

\section{Acknowledgements}

The authors are grateful to all those who supported us for answering questionnaire investigation.

\section{References}

Aburai, T., \& Takeyasu, K. (2013c). Bayesian Network Analysis and its Sensitivity Analysis for the Questionnaire Investigation on SNS. Journal of Computations \& Modelling, 3(4), 225-261.

Aburai, T., \& Takeyasu, K. (2013d). Overall Sensitivity Analysis Utilizing Bayesian Network for the 
Questionnaire Investigation on SNS. International Journal of Advanced Computer Science and Applications (IJACSA), 4(10), 59-72. https://doi.org/10.14569/IJACSA.2013.041011

Aburai, T., Higuchi, Y., \& Takeyasu, K. (2013b). Analysis of Questionnaire Investigation on SNS Utilizing Bayesian Network. Industrial Engineering \& Management Systems (IEMS), 12(2), 130-142. https://doi.org/10.7232/iems.2013.12.2.130

Aburai, T., Ishii, Y., \& Takeyasu, K. (2013a). An Analysis of User Attitudes to SNS. International Business Research (IBR), 6(5), 69-91.https://doi.org/10.5539/ibr.v6n5p69

Atami city. (2015). "2014 Survey of Tourist Behavior".

Doi, H. (2009). Evaluation of policies to build tourist destinations and statistical analysis" Nippon Hyoron Sha

Ingu, S., Uemura, M., Uchida, Y., Omiya, M., Miura, T., \& Hironori, H. (2017). A study on the application of geothermal power generation to local revitalization in Obama Town, Unzen City: in consideration of futurability in Obama. Environmental Science Research, Nagasaki University, 20(1), 51-63.

Inoue, A. (2017). Changes in Local Communities Brought by Municipal Mergers: From the Viewpoint of Tourism Promotion as the Main Industry. Bulletin of the Faculty of Regional Development Studies, Otemon Gakuin University, 2, 1-32.

Izupeninsula. (2015). https://www.jnto.go.jp/eng/location/rtg/pdf/pg-410.pdf\#search='Izupeninsula'

Japan Tourism Agency. (2015). Research study on economic impacts of tourism in Japan 2013, p3.

Kano, M. (2011). Characteristic analysis of Atami tourists: Reconsideration based on data add and modify. Shizuoka Economic Research, 16(2), 61-78, Shizuoka University.

KAWAZU. (2017). http://www.kawazu-onsen.com/eng/

Kotani, A. (2017). The implementation report of the Machi-lab shutter art project. Bulletin of Wakkanai Hokusei Gakuen University, 17, 207-218.

Ohkubo, Y. (2017). Current status and problems in Jigenji-dori shopping area : from a consumer questionnaire. Bulletin of Local Research, Kagoshima International University, 44(2), 1-15.

Shioya, H. (2009). Overview and application of tourism statistics: Analysis using statistical survey on overnight travels. Journal of Economic Structures, 17(1-2), 16-29, 2009. Pan Pacific Association of Input-Output Studies. https://doi.org/10.11107/papaios.17.1-2_16

Yoshida, I. (2009). Consideration on the Characteristic of Visitors' Activity and the Research Method for Tourist Visitors in Urban Areas. 


\section{APPENDIX 1}

Questionnaire Sheet about the Image Around the Shopping Street

1. How often do you come to this shopping street?

a. Everyday b. ( ) times a week c. ( ) times a month d. ( ) times a year

e. miscellaneous (

2. What is the purpose of visiting here? (Plural answers allowed)

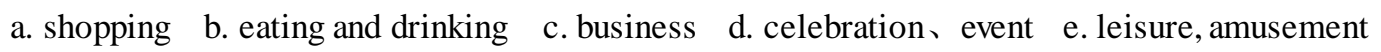

f. miscellaneous (

3. How do you feel about the image of the surrounding area at this shopping street?

Select the position

\begin{tabular}{|c|c|c|c|c|c|c|}
\hline Beautiful & • & - & • & - & $\cdot$ & Ugly \\
\hline $\begin{array}{r}\text { Of the united feeling } \\
\text { there is }\end{array}$ & $\cdot$ & $\cdot$ & $\cdot$ & - & $\cdot$ & Scattered \\
\hline Varied & $\cdot$ & - & $\cdot$ & - & • & Featureless \\
\hline New & $\cdot$ & $\cdot$ & $\cdot$ & - & $\cdot$ & Historic \\
\hline Full of nature & $\cdot$ & $\cdot$ & $\cdot$ & $\cdot$ & $\cdot$ & Urban \\
\hline Cheerful & $\cdot$ & $\cdot$ & $\cdot$ & $\cdot$ & $\cdot$ & Gloomy \\
\hline Individualistic & $\cdot$ & $\cdot$ & $\cdot$ & $\cdot$ & $\cdot$ & Conventional \\
\hline Friendly & $\cdot$ & $\cdot$ & $\cdot$ & $\cdot$ & $\cdot$ & Unfriendly \\
\hline Healed & $\cdot$ & $\cdot$ & $\cdot$ & $\cdot$ & $\cdot$ & Stimulated \\
\hline Open & $\cdot$ & $\cdot$ & $\cdot$ & $\cdot$ & $\cdot$ & exclusive \\
\hline Want to reside & $\cdot$ & $\cdot$ & $\cdot$ & $\cdot$ & $\cdot$ & Do not want to reside \\
\hline Warm & $\cdot$ & $\cdot$ & $\cdot$ & $\cdot$ & $\cdot$ & Aloof \\
\hline Fascinating & $\cdot$ & $\cdot$ & $\cdot$ & $\cdot$ & $\cdot$ & Not fascinating \\
\hline Want to play & $\cdot$ & - & - & • & • & $\begin{array}{l}\text { Want to examine } \\
\text { deliberately }\end{array}$ \\
\hline Lively & $\cdot$ & $\cdot$ & $\cdot$ & $\cdot$ & $\cdot$ & Calm \\
\hline Atmosphere of urban & $\cdot$ & $\cdot$ & $\cdot$ & $\cdot$ & $\cdot$ & Atmosphere of rural area \\
\hline
\end{tabular}

4. There are many old building at the age of nearly 50 years. Do you think we can still use them?
a. Can use it
b. Cannot use it
C. Have no idea

5. Is there any functions or facilities that will be useful?

\section{Comments}

\section{Sex}

a. Male b. Female

8. Age
a.10th b.20th c.30th d.40th e.50th f.6th g. More than70

9. Residence

a. Fuji City b. Fujinomiya City c. Numazu City d. Mishima City e. Shizuoka City f. Miscellaneous in Shizuoka Prefecture

g. Outside of Shizuoka Prefecture [ 


\section{APPENDIX 2}

Calculated posterior probability

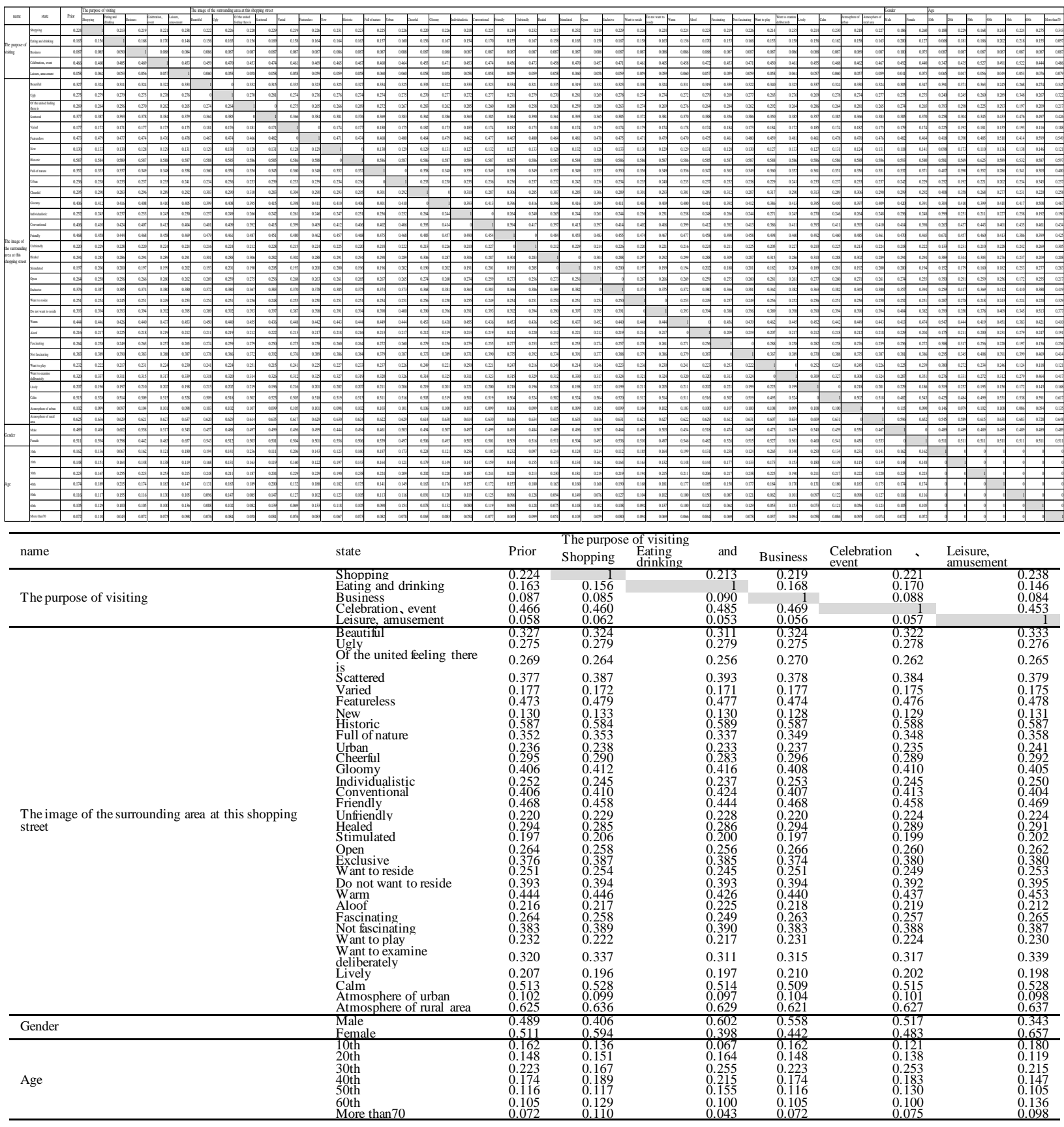

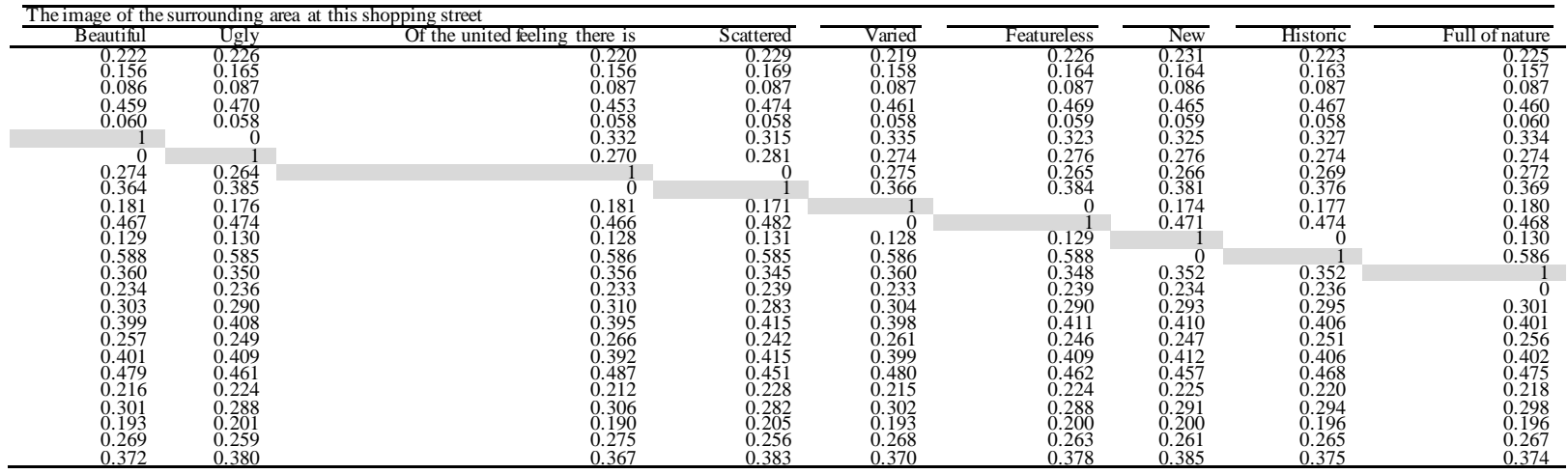




\begin{tabular}{|c|c|c|c|c|c|c|c|c|}
\hline 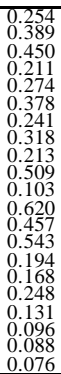 & 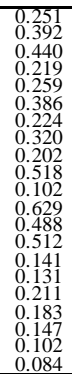 & 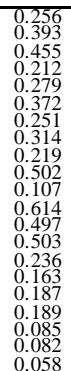 & $\begin{array}{ll} & 0.248 \\
0.397 \\
0.436 \\
0.222 \\
0.250 \\
0.392 \\
0.215 \\
0.326 \\
0.126 \\
0.523 \\
0.099 \\
0.635 \\
0.499 \\
0.501 \\
0.111 \\
0.119 \\
0.204 \\
0.200 \\
0.147 \\
0.139\end{array}$ & 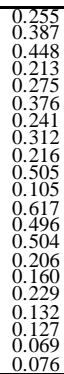 & 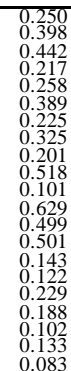 & 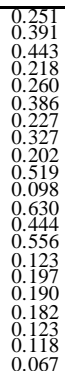 & 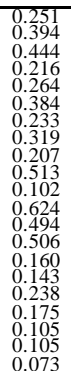 & $\begin{array}{l}0.254 \\
0.390 \\
0.449 \\
0.213 \\
0.272 \\
0.379 \\
0.3237 \\
0.320\end{array}$ \\
\hline
\end{tabular}

\begin{tabular}{|c|c|c|c|c|c|c|c|c|}
\hline Urban & Cheerful & Gloomy & Individualistic & Conventional & Friendly & Unfriendly & Healed & Stimulated \\
\hline 0.226 & 0.220 & 0.226 & 0.218 & 0.225 & 0.219 & 0.232 & 0.217 & 0.232 \\
\hline 0.160 & 0.156 & 0.167 & 0.154 & 0.170 & 0.155 & 0.167 & 0.158 & 0.165 \\
\hline 0.088 & 0.087 & 0.088 & 0.087 & 0.087 & 0.087 & 0.087 & 0.087 & 0.087 \\
\hline 0.464 & 0.455 & 0.471 & 0.453 & 0.474 & 0.456 & 0.473 & 0.458 & 0.470 \\
\hline 0.060 & 0.058 & 0.058 & 0.058 & 0.058 & 0.059 & 0.059 & 0.058 & 0.060 \\
\hline 0.325 & 0.335 & 0.322 & 0.333 & 0.323 & 0.334 & 0.321 & 0.335 & 0.319 \\
\hline 0.275 & 0.270 & 0.277 & 0.272 & 0.277 & 0.271 & 0.279 & 0.270 & 0.281 \\
\hline 0.267 & 0.283 & 0.262 & 0.285 & 0.260 & 0.280 & 0.258 & 0.281 & 0.259 \\
\hline 0.383 & 0.362 & 0.386 & 0.363 & 0.385 & 0.364 & 0.390 & 0.361 & 0.393 \\
\hline 0.175 & 0.182 & 0.173 & 0.183 & 0.174 & 0.182 & 0.173 & 0.181 & 0.174 \\
\hline 0.480 & 0.464 & 0.479 & 0.462 & 0.477 & 0.467 & 0.480 & 0.464 & 0.481 \\
\hline 0.129 & 0.129 & 0.131 & 0.127 & 0.132 & 0.127 & 0.133 & 0.128 & 0.132 \\
\hline 0.587 & 0.586 & 0.587 & 0.584 & 0.587 & 0.587 & 0.586 & 0.587 & 0.584 \\
\hline 0 & 0.358 & 0.348 & 0.359 & 0.349 & 0.358 & 0.349 & 0.357 & 0.349 \\
\hline 1 & 0.233 & 0.238 & 0.235 & 0.236 & 0.236 & 0.237 & 0.232 & 0.242 \\
\hline 0.292 & $\begin{array}{r}0.230 \\
1\end{array}$ & $\begin{array}{r}r .250 \\
0\end{array}$ & 0.310 & 0.287 & 0.306 & 0.285 & 0.307 & 0.285 \\
\hline 0.410 & 0 & 1 & 0.393 & 0.413 & 0.396 & 0.416 & 0.396 & 0.416 \\
\hline 0.252 & 0.264 & 0.244 & 1 & 0 & 0.264 & 0.240 & 0.263 & 0.244 \\
\hline 0.406 & 0.395 & 0.414 & 0 & 1 & 0.394 & 0.417 & 0.397 & 0.413 \\
\hline 0.468 & 0.485 & 0.457 & 0.490 & 0.454 & 1 & 0 & 0.484 & 0.455 \\
\hline 0.222 & 0.213 & 0.226 & 0.210 & 0.227 & 0 & 1 & 0.212 & 0.229 \\
\hline 0.289 & 0.306 & 0.287 & 0.306 & 0.287 & 0.304 & 0.283 & 1 & 0 \\
\hline 0.202 & 0.190 & 0.202 & 0.191 & 0.201 & 0.191 & 0.205 & 0 & 1 \\
\hline 0.265 & 0.274 & 0.260 & 0.274 & 0.259 & 0.273 & 0.256 & 0.273 & 0.256 \\
\hline 0.373 & 0.368 & 0.381 & 0.364 & 0.383 & 0.366 & 0.386 & 0.369 & 0.382 \\
\hline 0.251 & 0.256 & 0.250 & 0.255 & 0.249 & 0.254 & 0.251 & 0.254 & 0.251 \\
\hline 0.400 & 0.390 & 0.396 & 0.391 & 0.393 & 0.392 & 0.394 & 0.390 & 0.397 \\
\hline 0.444 & 0.453 & 0.438 & 0.455 & 0.436 & 0.453 & 0.436 & 0.452 & 0.437 \\
\hline 0.217 & 0.212 & 0.219 & 0.213 & 0.219 & 0.212 & 0.220 & 0.212 & 0.221 \\
\hline 0.260 & 0.279 & 0.256 & 0.279 & 0.255 & 0.277 & 0.253 & 0.277 & 0.253 \\
\hline 0.387 & 0.373 & 0.389 & 0.371 & 0.390 & 0.375 & 0.392 & 0.374 & 0.391 \\
\hline 0.226 & 0.249 & 0.221 & 0.250 & 0.221 & 0.247 & 0.216 & 0.249 & 0.214 \\
\hline 0.326 & 0.314 & 0.325 & 0.311 & 0.323 & 0.315 & 0.329 & 0.312 & 0.330 \\
\hline 0.206 & 0.219 & 0.201 & 0.221 & 0.200 & 0.218 & 0.196 & 0.218 & 0.198 \\
\hline 0.516 & 0.503 & 0.519 & 0.501 & 0.519 & 0.504 & 0.524 & 0.502 & 0.524 \\
\hline 0.101 & 0.106 & 0.100 & 0.107 & 0.099 & 0.106 & 0.099 & 0.105 & 0.099 \\
\hline 0.629 & 0.614 & 0.630 & 0.614 & 0.630 & 0.616 & 0.634 & 0.615 & 0.635 \\
\hline 0.503 & 0.494 & 0.507 & 0.497 & 0.499 & 0.491 & 0.484 & 0.489 & 0.496 \\
\hline 0.497 & 0.506 & 0.493 & 0.503 & 0.501 & 0.509 & 0.516 & 0.511 & 0.504 \\
\hline 0.173 & 0.224 & 0.121 & 0.256 & 0.105 & 0.232 & 0.097 & 0.214 & 0.124 \\
\hline 0.121 & 0.179 & 0.149 & 0.147 & 0.159 & 0.144 & 0.155 & 0.173 & 0.134 \\
\hline 0.209 & 0.202 & 0.220 & 0.187 & 0.244 & 0.220 & 0.213 & 0.230 & 0.181 \\
\hline 0.149 & 0.163 & 0.176 & 0.157 & 0.172 & 0.153 & 0.180 & 0.163 & 0.160 \\
\hline 0.116 & 0.091 & 0.120 & 0.119 & 0.125 & 0.096 & 0.128 & 0.094 & 0.149 \\
\hline 0.154 & 0.078 & 0.132 & 0.080 & 0.119 & 0.090 & 0.128 & 0.075 & 0.148 \\
\hline 0.078 & 0.063 & 0.083 & 0.054 & 0.077 & $\begin{array}{l}0.065 \\
0.065\end{array}$ & 0.099 & 0.051 & 0.103 \\
\hline
\end{tabular}

\begin{tabular}{|c|c|c|c|c|c|c|c|c|}
\hline Open & Exclusive & Want to reside & Do not want to reside & Warm & Aloof & Fascinating & Not fascinating & Want to play \\
\hline 0.219 & 0.229 & 0.226 & 0.224 & 0.224 & 0.223 & 0.219 & 0.226 & 0.214 \\
\hline 0.158 & 0.167 & 0.158 & 0.163 & 0.156 & 0.170 & 0.153 & 0.166 & 0.153 \\
\hline 0.088 & 0.087 & 0.087 & 0.088 & 0.086 & 0.088 & 0.087 & 0.087 & 0.087 \\
\hline 0.457 & 0.471 & 0.461 & 0.465 & 0.458 & 0.472 & 0.453 & 0.471 & 0.450 \\
\hline 0.058 & 0.059 & 0.059 & 0.059 & 0.060 & 0.057 & 0.059 & 0.059 & 0.058 \\
\hline 0.332 & 0.323 & 0.330 & 0.324 & 0.331 & 0.319 & 0.339 & 0.322 & 0.340 \\
\hline 0.269 & 0.278 & 0.274 & 0.274 & 0.272 & 0.279 & 0.269 & 0.277 & 0.265 \\
\hline 0.280 & 0.263 & 0.274 & 0.269 & 0.276 & 0.264 & 0.284 & 0.262 & 0.292 \\
\hline 0.365 & 0.385 & 0.372 & 0.381 & 0.370 & 0.388 & 0.356 & 0.386 & 0.350 \\
\hline 0.179 & 0.174 & 0.179 & 0.174 & 0.178 & 0.174 & 0.184 & 0.173 & 0.184 \\
\hline 0.470 & 0.475 & 0.471 & 0.479 & 0.470 & 0.475 & 0.461 & 0.480 & 0.459 \\
\hline 0.128 & 0.133 & 0.130 & 0.129 & 0.129 & 0.131 & 0.128 & 0.130 & 0.127 \\
\hline 0.588 & 0.586 & 0.586 & 0.587 & 0.586 & 0.585 & 0.587 & 0.587 & 0.588 \\
\hline 0.355 & 0.350 & 0.356 & 0.349 & 0.356 & 0.347 & 0.362 & 0.349 & 0.360 \\
\hline 0.236 & 0.234 & 0.235 & 0.240 & 0.235 & 0.237 & 0.232 & 0.238 & 0.229 \\
\hline 0.306 & 0.289 & 0.301 & 0.293 & 0.301 & 0.289 & 0.312 & 0.287 & 0.317 \\
\hline 0.399 & 0.411 & 0.403 & 0.409 & 0.400 & 0.411 & 0.392 & 0.412 & 0.386 \\
\hline 0.261 & 0.244 & $\begin{array}{l}0.256 \\
0.256\end{array}$ & 0.251 & 0.258 & 0.248 & 0.266 & 0.244 & 0.271 \\
\hline 0.397 & 0.414 & 0.402 & 0.406 & 0.399 & 0.412 & 0.392 & 0.413 & 0.386 \\
\hline 0.483 & 0.455 & 0.474 & 0.467 & 0.477 & 0.458 & 0.490 & 0.458 & 0.498 \\
\hline 0.214 & 0.226 & 0.220 & 0.221 & 0.216 & 0.224 & 0.211 & 0.225 & 0.205 \\
\hline 0.304 & 0.288 & 0.297 & 0.292 & 0.299 & 0.288 & 0.309 & 0.287 & 0.315 \\
\hline 0.191 & 0.200 & 0.197 & 0.199 & 0.194 & 0.202 & 0.188 & 0.201 & 0.182 \\
\hline & $\begin{array}{r}0.200 \\
0\end{array}$ & 0.267 & 0.266 & 0.269 & 0.259 & 0.275 & 0.260 & 0.281 \\
\hline 0 & 1 & 0.374 & 0.375 & 0.372 & 0.380 & 0.366 & 0.381 & 0.362 \\
\hline 0.254 & 0.250 & $\begin{array}{r}0.574 \\
1\end{array}$ & 0 & 0.253 & 0.249 & 0.257 & 0.249 & 0.256 \\
\hline 0.395 & 0.391 & 0 & 1 & 0.393 & 0.394 & 0.388 & 0.396 & 0.389 \\
\hline 0.452 & 0.440 & 0.448 & 0.444 & 1 & 0 & 0.456 & 0.439 & 0.462 \\
\hline 0.212 & 0.219 & 0.214 & 0.217 & 0 & 1 & 0.209 & 0.219 & 0.207 \\
\hline 0.274 & 0.257 & 0.270 & 0.261 & 0.271 & 0.256 & 1 & 0 & 0.288 \\
\hline 0.377 & 0.388 & 0.379 & 0.386 & 0.379 & 0.387 & 0 & 1 & 0.367 \\
\hline 0.246 & 0.223 & 0.236 & 0.230 & 0.241 & 0.223 & 0.253 & 0.222 & 1 \\
\hline 0.317 & 0.324 & 0.321 & 0.324 & 0.320 & 0.320 & 0.313 & 0.324 & 0 \\
\hline 0.217 & 0.199 & 0.211 & 0.205 & 0.211 & 0.202 & 0.221 & 0.199 & 0.225 \\
\hline 0.504 & 0.520 & 0.512 & 0.514 & 0.511 & 0.516 & 0.502 & 0.519 & 0.495 \\
\hline 0.105 & 0.099 & 0.104 & 0.102 & 0.103 & 0.100 & 0.107 & 0.100 & 0.108 \\
\hline 0.616 & 0.631 & 0.621 & 0.627 & 0.622 & 0.629 & 0.612 & 0.631 & 0.607 \\
\hline 0.507 & 0.464 & 0.490 & 0.503 & 0.454 & 0.518 & 0.474 & 0.485 & 0.473 \\
\hline 0.493 & 0.536 & 0.510 & 0.497 & 0.546 & 0.482 & 0.526 & 0.515 & 0.527 \\
\hline 0.214 & 0.112 & 0.185 & 0.164 & 0.199 & 0.131 & 0.238 & 0.124 & 0.265 \\
\hline 0.162 & 0.164 & 0.163 & 0.132 & 0.148 & 0.144 & 0.177 & 0.133 & 0.173 \\
\hline
\end{tabular}




\begin{tabular}{|c|c|c|}
\hline $\begin{array}{l}0.219 \\
0.168 \\
0.076 \\
0.102 \\
0.059 \\
\end{array}$ & $\begin{array}{l}0.219 \\
0.190 \\
0.127 \\
0.108 \\
0.080 \\
\end{array}$ & \\
\hline & & Want to ex \\
\hline & & \\
\hline & & \\
\hline & & \\
\hline & & \\
\hline & & \\
\hline & & \\
\hline & & \\
\hline & & \\
\hline & & \\
\hline & & \\
\hline & & \\
\hline & & \\
\hline & & \\
\hline & & \\
\hline & & \\
\hline & & \\
\hline & & \\
\hline & & \\
\hline & & \\
\hline & & \\
\hline & & \\
\hline & & \\
\hline & & \\
\hline & & \\
\hline & & \\
\hline & & \\
\hline & & \\
\hline & & \\
\hline & & \\
\hline & & \\
\hline & & \\
\hline & & \\
\hline & & \\
\hline & & \\
\hline & & \\
\hline & & \\
\hline & & \\
\hline & & \\
\hline & & \\
\hline & & \\
\hline & & \\
\hline & & \\
\hline & & \\
\hline & & \\
\hline & & \\
\hline & & \\
\hline Ger & & \\
\hline Male & & Female \\
\hline 0.186 & & 0.260 \\
\hline 0.200 & & 0.127 \\
\hline 0.100 & & 0.075 \\
\hline 0.492 & & 0.440 \\
\hline 0.041 & & 0.075 \\
\hline 0.305 & & 0.347 \\
\hline 0.275 & & 0.275 \\
\hline 0.274 & & 0.265 \\
\hline 0.385 & & 0.370 \\
\hline 0.179 & & 0.174 \\
\hline 0.482 & & 0.464 \\
\hline 0.118 & & 0.141 \\
\hline 0.593 & & 0.580 \\
\hline 0.332 & & 0.371 \\
\hline 0.242 & & 0.229 \\
\hline 0.299 & & 0.292 \\
\hline 0.420 & & 0.391 \\
\hline 0.256 & & 0.248 \\
\hline 0.414 & & 0.398 \\
\hline 0.470 & & 0.465 \\
\hline 0.218 & & 0.222 \\
\hline 0.294 & & 0.294 \\
\hline 0.200 & & 0.194 \\
\hline 0.274 & & 0.255 \\
\hline 0.357 & & 0.394 \\
\hline 0.252 & & 0.251 \\
\hline 0.404 & & 0.382 \\
\hline 0.413 & & 0.474 \\
\hline 0.229 & & 0.204 \\
\hline 0.256 & & 0.272 \\
\hline 0.381 & & 0.386 \\
\hline 0.225 & & 0.239 \\
\hline 0.287 & & 0.351 \\
\hline 0.229 & & 0.186 \\
\hline $\begin{array}{l}0.429 \\
0.482\end{array}$ & & $\begin{array}{l}0.100 \\
0.543\end{array}$ \\
\hline 0.115 & & 0.090 \\
\hline 0.596 & & 0.652 \\
\hline 1 & & \\
\hline 0 & & 1 \\
\hline 0.162 & & 0.162 \\
\hline 0.148 & & 0.148 \\
\hline $\begin{array}{l}0.140 \\
0.223\end{array}$ & & $\begin{array}{l}0.140 \\
0.223\end{array}$ \\
\hline 0.174 & & 0.174 \\
\hline 0.116 & & 0.116 \\
\hline 0.105 & & 0.105 \\
\hline 0.072 & & 0.072 \\
\hline
\end{tabular}




\section{APPENDIX 3}

\section{Difference of probability}

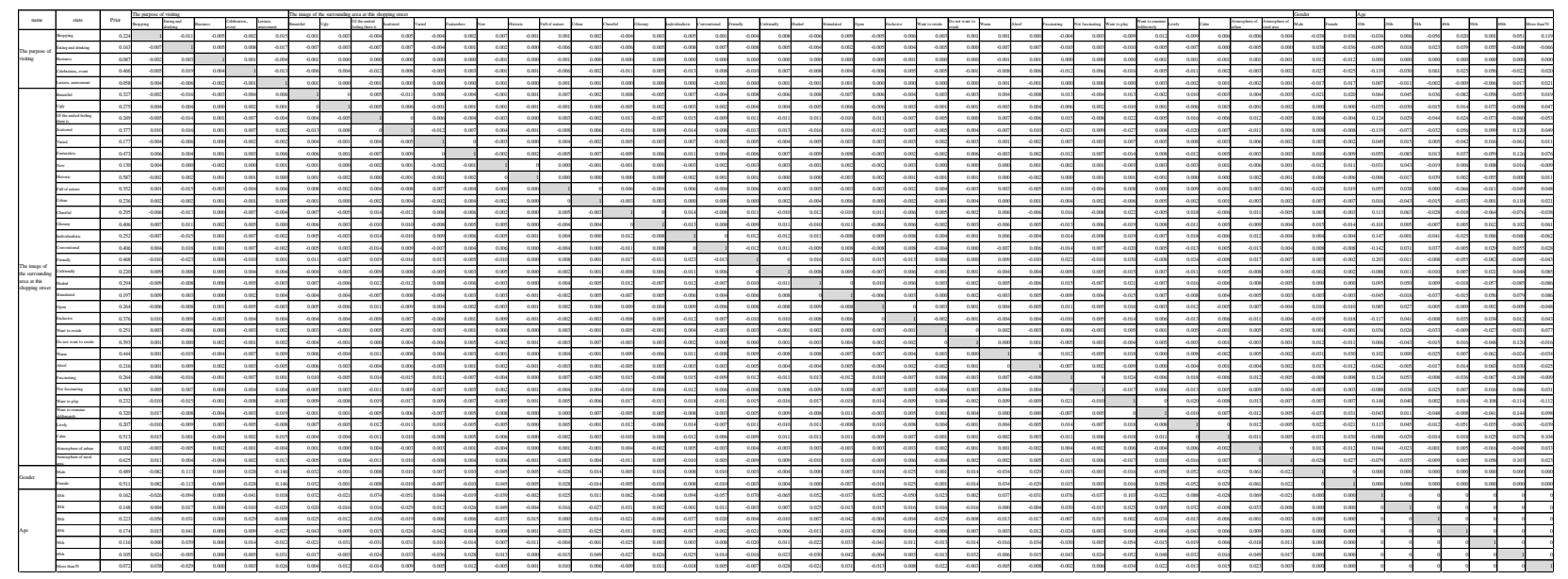

\begin{tabular}{|c|c|c|c|c|c|c|c|c|c|}
\hline \multirow{2}{*}{ name } & \multirow{2}{*}{\multicolumn{2}{|c|}{ state }} & \multirow[b]{2}{*}{ Prior } & \multicolumn{5}{|c|}{ The purpose of visiting } & \\
\hline & & & & Shopping & $\begin{array}{l}\text { Eating and } \\
\text { drinking }\end{array}$ & Business & $\begin{array}{l}\text { Celebration, } \\
\text { event }\end{array}$ & $\begin{array}{l}\text { Leisure, } \\
\text { amusement }\end{array}$ & \\
\hline \multirow{5}{*}{ The purpose of visiting } & \multicolumn{2}{|c|}{ Shopping } & 0.224 & 1 & -0.011 & -0.005 & -0.002 & 0.015 & \\
\hline & \multicolumn{2}{|c|}{ Eating and drinking } & 0.163 & -0.007 & 1 & 0.005 & 0.008 & -0.017 & \\
\hline & \multicolumn{2}{|c|}{ Business } & 0.087 & -0.002 & 0.003 & 1 & 0.001 & -0.004 & \\
\hline & \multirow{2}{*}{\multicolumn{2}{|c|}{ Celebration, event }} & 0.466 & -0.005 & 0.019 & 0.004 & 1 & -0.013 & \\
\hline & & & 0.058 & 0.004 & -0.006 & -0.002 & -0.001 & 1 & \\
\hline & & & 0.327 & -0.002 & -0.016 & -0.003 & -0.004 & 0.006 & \\
\hline & \multicolumn{2}{|l|}{ Ugly } & 0.275 & 0.004 & 0.004 & 0.000 & 0.002 & 0.001 & \\
\hline & \multicolumn{2}{|c|}{$\begin{array}{l}\text { Of the united feeling } \\
\text { there is }\end{array}$} & 0.269 & -0.005 & -0.014 & 0.001 & -0.007 & -0.004 & \\
\hline & Scattered & & 0.377 & 0.010 & 0.016 & 0.001 & 0.007 & 0.002 & \\
\hline & Varied & & 0.177 & -0.004 & -0.006 & 0.000 & -0.002 & -0.002 & \\
\hline & Featureless & & 0.473 & 0.006 & 0.004 & 0.001 & 0.003 & 0.006 & \\
\hline & New & & 0.130 & 0.004 & 0.000 & -0.002 & 0.000 & 0.001 & \\
\hline & Historic & & 0.587 & -0.002 & 0.002 & 0.001 & 0.001 & 0.000 & \\
\hline & Full of nat & & 0.352 & 0.001 & -0.015 & -0.003 & -0.004 & 0.006 & \\
\hline & Urban & & 0.236 & 0.002 & -0.002 & 0.001 & -0.001 & 0.005 & \\
\hline & Cheerful & & 0.295 & -0.006 & -0.013 & 0.000 & -0.007 & -0.004 & \\
\hline & Gloomy & & 0.406 & 0.007 & 0.011 & 0.002 & 0.005 & 0.000 & \\
\hline & Individuali & & 0.252 & -0.007 & -0.015 & 0.001 & -0.007 & -0.002 & \\
\hline & Conventio & & 0.406 & 0.004 & 0.018 & 0.001 & 0.007 & -0.002 & \\
\hline & Friendly & & 0.468 & -0.010 & -0.023 & 0.000 & -0.010 & 0.001 & \\
\hline & Unfriendly & & 0.220 & 0.009 & 0.008 & 0.000 & 0.004 & 0.004 & \\
\hline The image of the surrounding & Healed & & 0.294 & -0.009 & -0.008 & 0.000 & -0.005 & -0.003 & \\
\hline & Stimulated & & 0.197 & 0.009 & 0.003 & 0.000 & 0.002 & 0.004 & \\
\hline & Open & & 0.264 & -0.006 & -0.008 & 0.001 & -0.005 & -0.003 & \\
\hline & Exclusive & & 0.376 & 0.010 & 0.009 & -0.003 & 0.004 & 0.004 & \\
\hline & Want to res & & 0.251 & 0.003 & -0.006 & 0.000 & -0.003 & 0.002 & \\
\hline & Do not war & reside & 0.393 & 0.001 & 0.000 & 0.002 & -0.001 & 0.002 & \\
\hline & Warm & & 0.444 & 0.001 & -0.019 & -0.004 & -0.007 & 0.009 & \\
\hline & Aloof & & 0.216 & 0.001 & 0.009 & 0.002 & 0.003 & -0.005 & \\
\hline & Fascinatin & & 0.264 & -0.006 & -0.016 & -0.001 & -0.007 & 0.001 & \\
\hline & Not fascina & & 0.383 & 0.005 & 0.007 & 0.000 & 0.004 & 0.004 & \\
\hline & Want to $\mathrm{pl}$ & & 0.232 & -0.010 & -0.015 & -0.001 & -0.008 & -0.003 & \\
\hline & $\begin{array}{l}\text { Want to ex } \\
\text { deliberatel }\end{array}$ & & 0.320 & 0.017 & -0.008 & -0.004 & -0.003 & 0.019 & \\
\hline & Lively & & 0.207 & -0.010 & -0.009 & 0.003 & -0.005 & -0.008 & \\
\hline & Calm & & 0.513 & 0.015 & 0.001 & -0.004 & 0.002 & 0.015 & \\
\hline & Atmospher & urban & 0.102 & -0.003 & -0.005 & 0.002 & -0.001 & -0.004 & \\
\hline & $\begin{array}{l}\text { Atmospher } \\
\text { area }\end{array}$ & rural & 0.625 & 0.011 & 0.004 & -0.004 & 0.002 & 0.013 & \\
\hline Gender & Male & & 0.489 & -0.082 & 0.113 & 0.069 & 0.028 & -0.146 & \\
\hline Gender & Female & & 0.511 & 0.082 & -0.113 & -0.069 & -0.028 & 0.146 & \\
\hline & 10th & & 0.162 & -0.026 & -0.094 & 0.000 & -0.041 & 0.018 & \\
\hline & 20th & & 0.148 & 0.004 & 0.017 & 0.000 & -0.010 & -0.029 & \\
\hline & 30th & & 0.223 & -0.056 & 0.031 & 0.000 & 0.029 & -0.008 & \\
\hline Age & 40th & & 0.174 & 0.015 & 0.041 & 0.000 & 0.009 & -0.027 & \\
\hline & 50 th & & 0.116 & 0.000 & 0.039 & 0.000 & 0.014 & -0.012 & \\
\hline & 60th & & 0.105 & 0.024 & -0.005 & 0.000 & -0.005 & 0.031 & \\
\hline & More than & & 0.072 & 0.038 & -0.029 & 0.000 & 0.003 & 0.026 & \\
\hline The image of the surroundin & this shoppin & & & & & & & & \\
\hline Beautiful & Ugly & $\begin{array}{l}\text { Of the united } \\
\text { feeling there is }\end{array}$ & & Scattered & Varied & ureless & New & Historic & $\begin{array}{l}\text { Full of } \\
\text { nature }\end{array}$ \\
\hline-0.001 & 0.003 & -0.004 & & 0.005 & -0.004 & 0.002 & 0.007 & -0.001 & 0.001 \\
\hline-0.007 & 0.003 & -0.007 & & 0.007 & -0.004 & 0.001 & 0.002 & 0.000 & -0.006 \\
\hline-0.001 & 0.000 & 0.000 & & 0.000 & 0.000 & 0.000 & -0.001 & 0.000 & -0.001 \\
\hline-0.006 & 0.004 & -0.012 & & 0.008 & -0.005 & 0.003 & -0.001 & 0.001 & -0.006 \\
\hline 0.001 & 0.000 & -0.001 & & 0.000 & 0.000 & 0.000 & 0.001 & 0.000 & 0.001 \\
\hline 1 & 0 & 0.005 & & -0.011 & 0.008 & -0.004 & -0.001 & 0.001 & 0.007 \\
\hline 0 & 1 & -0.005 & & 0.006 & -0.001 & 0.001 & 0.001 & -0.001 & -0.001 \\
\hline 0.004 & -0.005 & 1 & & 0 & 0.006 & -0.004 & -0.003 & 0.000 & 0.003 \\
\hline-0.013 & 0.008 & 0 & & 1 & -0.012 & 0.007 & 0.004 & -0.001 & -0.008 \\
\hline 0.004 & -0.001 & 0.004 & & -0.005 & 1 & 0 & -0.003 & 0.000 & 0.004 \\
\hline-0.006 & 0.001 & -0.007 & & 0.009 & 0 & 1 & -0.002 & 0.002 & -0.005 \\
\hline-0.001 & 0.000 & -0.002 & & 0.001 & -0.002 & -0.001 & 1 & 0 & 0.000 \\
\hline 0.001 & -0.002 & 0.000 & & -0.001 & -0.001 & 0.002 & 0 & 1 & 0.000 \\
\hline 0.008 & -0.002 & 0.004 & & -0.008 & 0.007 & -0.004 & 0.000 & 0.000 & 1 \\
\hline
\end{tabular}


Vol. 11, No. 2; 2018

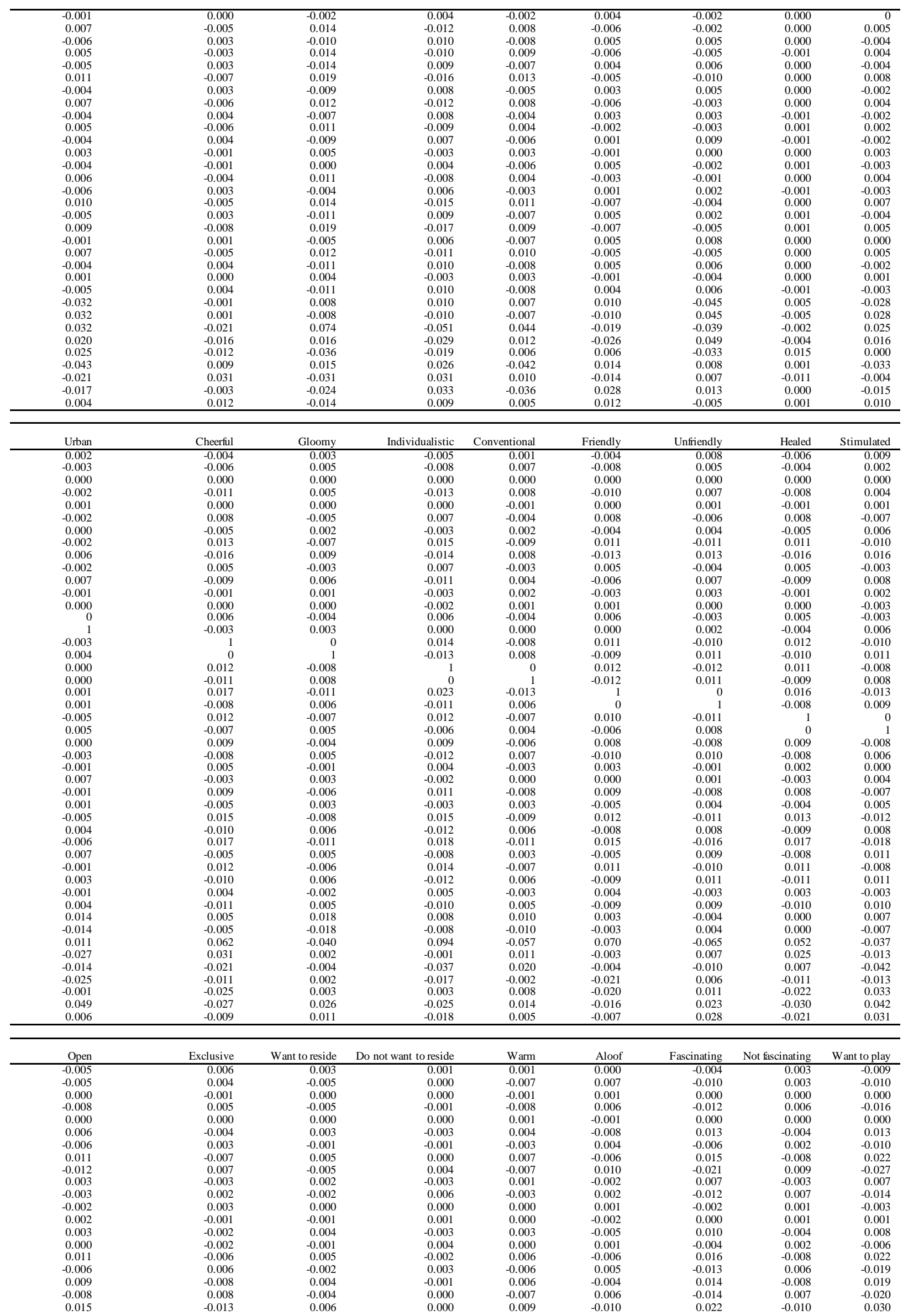




\begin{tabular}{|c|c|c|c|c|c|c|c|c|}
\hline-0.007 & 0.006 & -0.001 & 0.001 & -0.004 & 0.004 & -0.009 & 0.005 & -0.015 \\
\hline 0.010 & -0.006 & 0.003 & -0.002 & 0.005 & -0.006 & 0.015 & -0.007 & 0.021 \\
\hline-0.006 & 0.003 & 0.000 & 0.002 & -0.003 & 0.005 & -0.009 & 0.004 & -0.015 \\
\hline 1 & 0 & 0.003 & 0.001 & 0.004 & -0.005 & 0.011 & -0.005 & 0.016 \\
\hline 0 & 1 & -0.002 & -0.001 & -0.004 & 0.004 & -0.010 & 0.005 & -0.014 \\
\hline 0.003 & -0.001 & 1 & 0 & 0.002 & -0.003 & 0.006 & -0.003 & 0.005 \\
\hline 0.002 & -0.002 & 0 & 1 & 0.000 & 0.001 & -0.005 & 0.003 & -0.004 \\
\hline 0.007 & -0.004 & 0.003 & 0.000 & 1 & 0 & 0.012 & -0.005 & 0.018 \\
\hline-0.004 & 0.002 & -0.002 & 0.001 & 0 & 1 & -0.007 & 0.002 & -0.009 \\
\hline 0.010 & -0.007 & 0.006 & -0.003 & 0.007 & -0.008 & 1 & 0 & 0.024 \\
\hline-0.007 & 0.005 & -0.004 & 0.003 & -0.004 & 0.004 & 0 & 1 & -0.017 \\
\hline 0.014 & -0.009 & 0.004 & -0.002 & 0.009 & -0.009 & 0.021 & -0.010 & 1 \\
\hline-0.003 & 0.005 & 0.001 & 0.004 & 0.000 & 0.000 & -0.007 & 0.005 & 0 \\
\hline 0.010 & -0.008 & 0.004 & -0.001 & 0.004 & -0.005 & 0.014 & -0.007 & 0.018 \\
\hline-0.009 & 0.007 & -0.001 & 0.001 & -0.002 & 0.003 & -0.011 & 0.006 & -0.018 \\
\hline 0.003 & -0.003 & 0.002 & -0.001 & 0.001 & -0.002 & 0.004 & -0.002 & 0.006 \\
\hline-0.009 & 0.006 & -0.004 & 0.002 & -0.002 & 0.005 & -0.013 & 0.006 & -0.017 \\
\hline 0.018 & -0.025 & 0.001 & 0.014 & -0.034 & 0.029 & -0.015 & -0.003 & -0.016 \\
\hline-0.018 & 0.025 & -0.001 & -0.014 & 0.034 & -0.029 & 0.015 & 0.003 & 0.016 \\
\hline 0.052 & -0.050 & 0.023 & 0.002 & 0.037 & -0.031 & 0.076 & -0.037 & 0.103 \\
\hline 0.015 & 0.016 & 0.016 & -0.016 & 0.000 & -0.004 & 0.030 & -0.015 & 0.025 \\
\hline-0.004 & -0.004 & -0.029 & -0.008 & -0.013 & -0.017 & -0.007 & 0.015 & 0.002 \\
\hline-0.006 & 0.016 & -0.006 & 0.007 & 0.003 & 0.012 & -0.024 & 0.003 & 0.010 \\
\hline-0.041 & 0.011 & -0.013 & -0.014 & -0.016 & 0.034 & -0.030 & 0.005 & -0.054 \\
\hline-0.004 & 0.003 & -0.013 & 0.032 & -0.006 & 0.015 & -0.043 & 0.024 & -0.052 \\
\hline-0.013 & 0.008 & 0.022 & -0.003 & -0.005 & -0.008 & -0.002 & 0.006 & -0.034 \\
\hline
\end{tabular}

\begin{tabular}{|c|c|c|c|c|}
\hline Want to examine deliberately & Lively & Calm & $\begin{array}{c}\text { Atmosphere of } \\
\text { urban }\end{array}$ & $\begin{array}{c}\text { Atmosphere of } \\
\text { rural area }\end{array}$ \\
\hline 0.012 & -0.009 & 0.006 & -0.006 & 0.004 \\
\hline-0.005 & -0.007 & 0.000 & -0.005 & 0.000 \\
\hline-0.001 & 0.001 & -0.001 & 0.001 & -0.001 \\
\hline-0.005 & -0.011 & 0.002 & -0.003 & 0.002 \\
\hline 0.003 & -0.002 & 0.001 & -0.002 & 0.001 \\
\hline-0.002 & 0.010 & -0.003 & 0.004 & -0.003 \\
\hline 0.001 & -0.006 & 0.003 & -0.001 & 0.002 \\
\hline-0.005 & 0.016 & -0.006 & 0.012 & -0.005 \\
\hline 0.008 & -0.020 & 0.007 & -0.011 & 0.006 \\
\hline-0.005 & 0.008 & -0.003 & 0.006 & -0.002 \\
\hline 0.008 & -0.012 & 0.005 & -0.003 & 0.003 \\
\hline 0.003 & -0.003 & 0.001 & -0.006 & 0.001 \\
\hline-0.001 & 0.000 & 0.000 & 0.002 & -0.001 \\
\hline 0.000 & 0.009 & -0.001 & 0.003 & -0.001 \\
\hline 0.005 & -0.002 & 0.001 & -0.003 & 0.002 \\
\hline-0.005 & 0.018 & -0.006 & 0.011 & -0.005 \\
\hline 0.008 & -0.011 & 0.005 & -0.009 & 0.004 \\
\hline-0.007 & 0.018 & -0.006 & 0.012 & -0.004 \\
\hline 0.005 & -0.013 & 0.005 & -0.013 & 0.004 \\
\hline-0.008 & 0.024 & -0.008 & 0.017 & -0.007 \\
\hline 0.007 & -0.011 & 0.005 & -0.008 & 0.003 \\
\hline-0.007 & 0.016 & -0.006 & 0.008 & -0.005 \\
\hline 0.007 & -0.008 & 0.004 & -0.005 & 0.003 \\
\hline-0.003 & 0.012 & -0.005 & 0.007 & -0.004 \\
\hline 0.006 & -0.013 & 0.006 & -0.011 & 0.004 \\
\hline 0.001 & 0.005 & -0.001 & 0.005 & -0.002 \\
\hline 0.005 & -0.003 & 0.001 & -0.003 & 0.001 \\
\hline 0.000 & 0.008 & -0.002 & 0.005 & -0.002 \\
\hline 0.000 & -0.004 & 0.001 & -0.004 & 0.002 \\
\hline-0.006 & 0.018 & -0.006 & 0.012 & -0.005 \\
\hline 0.006 & -0.013 & 0.005 & -0.009 & 0.004 \\
\hline 0 & 0.020 & -0.008 & 0.013 & -0.007 \\
\hline 1 & -0.010 & 0.007 & -0.012 & 0.005 \\
\hline-0.008 & 1 & 0 & 0.012 & -0.005 \\
\hline 0.011 & 0 & 1 & -0.011 & 0.005 \\
\hline-0.004 & 0.006 & -0.002 & 1 & 0 \\
\hline 0.010 & -0.016 & 0.007 & 0 & 1 \\
\hline-0.050 & 0.052 & -0.029 & 0.061 & -0.022 \\
\hline 0.050 & -0.052 & 0.029 & -0.061 & 0.022 \\
\hline-0.022 & 0.088 & -0.028 & 0.069 & -0.021 \\
\hline 0.005 & 0.032 & -0.008 & -0.033 & -0.008 \\
\hline-0.034 & -0.013 & -0.006 & -0.001 & -0.003 \\
\hline-0.004 & -0.043 & 0.006 & 0.009 & 0.001 \\
\hline-0.015 & -0.019 & 0.006 & -0.018 & 0.011 \\
\hline 0.048 & -0.032 & 0.016 & -0.049 & 0.017 \\
\hline 0.022 & -0.013 & 0.015 & 0.023 & 0.003 \\
\hline
\end{tabular}

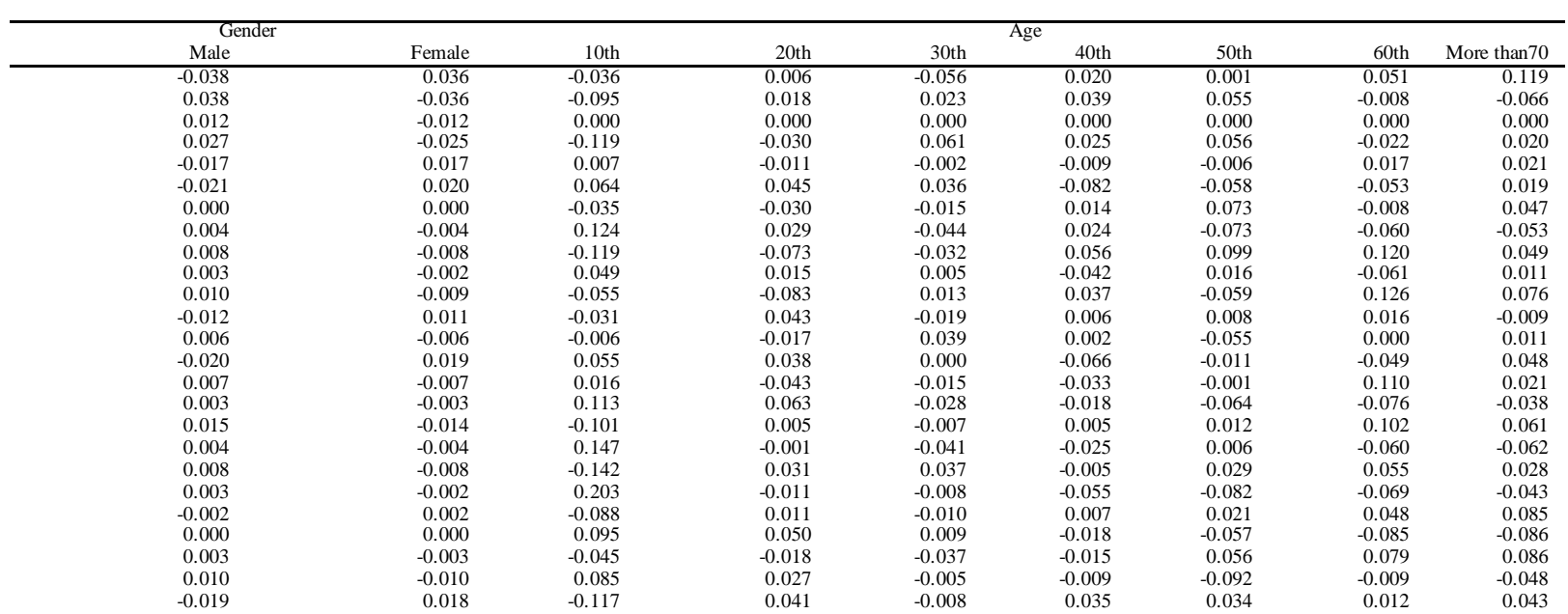




\begin{tabular}{|c|c|c|c|c|c|c|c|c|}
\hline 0.001 & -0.001 & 0.036 & 0.026 & -0.033 & -0.009 & -0.027 & -0.031 & 0.077 \\
\hline 0.012 & -0.011 & 0.006 & -0.043 & -0.015 & 0.016 & -0.048 & 0.120 & -0.016 \\
\hline-0.031 & 0.030 & 0.102 & 0.000 & -0.025 & 0.007 & -0.062 & -0.024 & -0.034 \\
\hline 0.013 & -0.012 & -0.042 & -0.005 & -0.017 & 0.014 & 0.063 & 0.030 & -0.025 \\
\hline-0.008 & 0.008 & 0.124 & 0.053 & -0.008 & -0.036 & -0.067 & -0.108 & -0.009 \\
\hline-0.003 & 0.003 & -0.088 & -0.038 & 0.025 & 0.007 & 0.016 & 0.086 & 0.031 \\
\hline-0.007 & 0.007 & 0.148 & 0.040 & 0.002 & 0.014 & -0.108 & -0.114 & -0.112 \\
\hline-0.033 & 0.031 & -0.043 & 0.011 & -0.048 & -0.008 & -0.041 & 0.144 & 0.098 \\
\hline 0.022 & -0.021 & 0.113 & 0.045 & -0.012 & -0.051 & -0.035 & -0.063 & -0.039 \\
\hline-0.031 & 0.030 & -0.088 & -0.029 & -0.014 & 0.018 & 0.025 & 0.078 & 0.104 \\
\hline 0.013 & -0.012 & 0.044 & -0.023 & -0.001 & 0.005 & -0.016 & -0.048 & 0.033 \\
\hline-0.028 & 0.027 & -0.079 & -0.035 & -0.009 & 0.005 & 0.058 & 0.103 & 0.023 \\
\hline 1 & 0 & 0.000 & 0.000 & 0.000 & 0.000 & 0.000 & 0.000 & 0.000 \\
\hline 0 & 1 & 0.000 & 0.000 & 0.000 & 0.000 & 0.000 & 0.000 & 0.000 \\
\hline 0.000 & 0.000 & 1 & 0 & 0 & 0 & 0 & 0 & 0 \\
\hline 0.000 & 0.000 & 0 & 1 & 0 & 0 & 0 & 0 & 0 \\
\hline 0.000 & 0.000 & 0 & 0 & 1 & 0 & 0 & 0 & 0 \\
\hline 0.000 & 0.000 & 0 & 0 & 0 & 1 & 0 & 0 & 0 \\
\hline 0.000 & 0.000 & 0 & 0 & 0 & 0 & 1 & 0 & 0 \\
\hline 0.000 & 0.000 & 0 & 0 & 0 & 0 & 0 & 1 & 0 \\
\hline 0.000 & 0.000 & 0 & 0 & 0 & 0 & 0 & 0 & 1 \\
\hline
\end{tabular}

\section{Copyrights}

Copyright for this article is retained by the author(s), with first publication rights granted to the journal.

This is an open-access article distributed under the terms and conditions of the Creative Commons Attribution license (http://creativecommons.org/licenses/by/4.0/). 